Case Histories in Sand-over-Clay

Muhammad Shazzad Hossain ${ }^{1}$, Pan $^{\mathrm{Hu}^{2}}$, Mark Jason Cassidy ${ }^{3}$, David Menzies ${ }^{4}$, and Audrey Wingate ${ }^{5}$

${ }^{1}$ Corresponding Author, Senior Research Fellow (BEng, MEng, PhD, MIEAust), Centre for Offshore Foundation Systems (COFS), The University of Western Australia, 35 Stirling Highway, Crawley, WA 6009, Tel: +61 86488 7358, Fax: +61 86488 1044, Email: muhammad.hossain@uwa.edu.au

$13{ }^{2}$ Research Associate (BEng, PhD), Centre for Offshore Foundation Systems (COFS), The University of Western Australia, 35 Stirling Highway, Crawley, WA 6009, Tel: +61 86488 4780, Fax: +61 86488 1044, Email: pan.hu@uwa.edu.au

${ }^{3}$ Professor (FTSE, FIEAust, GAICD) Dean and Professor of Civil Engineering, Melbourne School of Engineering, Doug McDonell Building, The University of Melbourne, Victoria 3010, Australia, Tel: +61 38344 6619, Email: mark.cassidy@unimelb.edu.au

${ }^{4}$ Head of MatthewsDaniel Geotechnical Group, MatthewsDaniel, 4544 Post Oak Place, Suite 160, Houston, Texas 77027, Tel: +1 713622 1633, Email: davidmenzies@matdan.com

${ }^{5}$ Former Senior Project Engineer, Fugro-McClelland Marine Geosciences, Inc., 6100 Hillcroft (77081), P.O. Box 740010, Houston, Texas 77274, Tel: +1 713369 5600, Email: Audrey.B.Wingate@gmail.com

- Number of Words: 5076 (text only)

- Number of Tables: 03

- Number of Figures: 06 


\title{
Measured and Calculated Spudcan Penetration Profiles for Case Histories in Sand-over-Clay
}

\author{
ABSTRACT
}

This paper reports five case histories of jack-up rig installation in layered soil profiles where a dominate feature was a stronger sand layer overlaying a weaker clay layer. In all cases a relatively continuous load-penetration profile was measured during installation of each of the three spudcan foundations. Summary site-investigation data is provided and consisted of mainly torvane, minature vane, unconsolidated undrained triaxial and pocket penetrometer tests for determining undrained shear strength of the clays and blow counts for deriving the relative density of sand. A statistical averaging method recommended in the InSafeJIP guidelines was used to provide the best fit of the undrained shear strength profile in the clay as this then allowed for spudcan load-penetration profiles to be estimated without introduction of user interpretation or bias. Sand properties were taken as provided in the original siteinvestigation report. Comparisons between load-penetration profiles calculated using the industry-standard ISO guideline, more recently proposed mechanism-based calculation method and three-dimensional large deformation finite element simulations are made with the measured data, leading to valuable insights for practitioners for estimating behaviour of jackup installations in problematic sand-over-clay soil profiles.

KEYWORDS: bearing capacity; clays; failure; footings/foundations; numerical modelling; offshore engineering; sands 


\subsection{Spudcan Punch-Through in a Layered Soil}

51

Spudcan-supported jack-up rig installation and preloading in stratified seabed deposits which contain a strong layer of sand over a weak clay layer remains problematic within the offshore industry (Osborne and Paisley 2002; Osborne et al. 2009; Jack et al. 2013). Punching the sand layer into the weaker clay can cause a rapid penetration, potentially buckling the leg and even toppling the jack-up. Layered soils are prevalent in the Sunda Shelf offshore Malaysia, Australia's Bass Strait and North-West Shelf, the Gulf of Thailand, the South China Sea, offshore Bombay High, the Persian Gulf, and even the Gulf of Mexico (InSafeJIP 2011; Menzies and Lopez 2011).

This background has motivated a number of researchers to explore spudcan penetration in two-layer sand-over-clay soils and multilayer soils with interbedded sand layers (Hanna and Meyerhof 1980; Craig and Chua 1990; Teh et al. 2008, 2010; Qiu and Henke 2011; Qiu and Grabe 2012; Tho et al. 2012; Hossain et al. 2012; Lee et al. 2013a, 2013b; Hossain, 2014; Hu et al. 2014a, 2016; Ullah et al. 2017a, b) and this has led to new mechanism-based design approaches for assessing spudcan penetration resistance (Teh et al. 2009; Lee et al. 2009, 2013b; Hu et al. 2015a, 2017, 2018). Synthesis of centrifuge model test data and large deformation finite element (LDFE) analysis results have underpinned these new approaches with measured data from jack-up installations in the field rarely reported in the public domain. This hinders an immediate evaluation of the performance of these methods in estimating the spudcan penetration resistance in offshore sand-over-clay deposits. As such, the recently finalised version of ISO guidelines 19905-1 (ISO, 2012) still recommends the 'punching shear' (Hanna and Meyerhof 1980) and 'projected area' (Terzaghi and Peck 1948) methods (see review in Cassidy et al. 2015). The approach by Teh et al. (2009) was suggested as an alternative method. 
The aim of this paper is to present five case histories of jack-up installations in soil profiles with a dominant sand-over-clay strata. Retrospective estimation of the spudcan loadpenetration profiles at each site, calculated using the ISO methods, the mechanism-based approach of $\mathrm{Hu}$ et al. (2015a, 2017, 2018) and computed using three-dimensional large deformation finite element (LDFE) analyses, are then compared and the lessons learnt are discussed. Only the main methods (punching shear and projected area) suggested in ISO, which are commonly used by the industries, were considered.

\subsection{Case Histories}

Five case histories were collected from different locations in the Gulf of Mexico, as summarised in Table 1. The field data are reported here for the first time. The soils were twoand four-layer deposits (within the depth of interest) consisting of alternating layers of loose to very dense fine silica sand and soft to stiff clay with an undrained shear strength increasing with depth. The documentation of these case histories includes (a) site-specific soil information, (b) accurate spudcan penetration records (excluding the unload-reload steps), and (c) well-documented spudcan geometries and applied loading. The full details of the soil profiles and spudcan geometries are given in Tables 1 and 2.

\subsubsection{Soil investigation and undrained shear strength profile}

At each site, a single boring was drilled and sampled by driving thin-wall 2.25-inch (57.15 $\mathrm{mm}$ ) diameter Shelby tubes and pushing 3.0-in tubes. The samples were wireline driven with a slide-type (165 pounds or $74.84 \mathrm{~kg}$ ) hammer on a winch that can free fall $5 \mathrm{ft}(1.52 \mathrm{~m})$. For clay, the offshore and onshore laboratory tests carried out on the cored samples included the use of (a) pocket penetrometer (PP), (b) torvane, (c) remote vane, (d) miniature vane, and (e) unconsolidated undrained triaxial (UU) tests. In this study, the undrained shear strength, $s_{\mathrm{u}}$, 
97 profiles are adequately represented using a trend line that increases linearly with depth, which

98 can be expressed as

100 where $s_{\mathrm{um}}$ is the undrained shear strength at the sand-clay interface and $k$ is the rate of

101 increase in $s_{\mathrm{u}}$ with depth $z$. The selection of the design undrained shear strength $s_{\mathrm{u}}$ was based 102 on a statistical method (Lacasse et al. 2007; InSafeJIP 2011), with the best linear profile 103

104

105

106 where

107

108 obtained as

$$
s_{\mathrm{u}}=s_{\mathrm{um}}+k \mathrm{Z}
$$

$$
\begin{gathered}
k=\frac{\sum_{i=1}^{\mathrm{n}}\left(z_{\mathrm{i}}-\bar{Z}\right)\left(S_{\mathrm{u}, \mathrm{i}}-\bar{S}_{\mathrm{u}}\right)}{\sum_{i=1}^{\mathrm{n}}\left(z_{\mathrm{i}}-\bar{Z}\right)^{2}} \\
S_{\mathrm{um}}=\bar{S}_{\mathrm{u}}-k \bar{Z}
\end{gathered}
$$

$$
\begin{gathered}
\bar{z}=\frac{1}{n} \sum_{i=1}^{n} z_{\mathrm{i}} \\
\bar{S}_{\mathrm{u}}=\frac{1}{n} \sum_{i=1}^{n} S_{\mathrm{u}, \mathrm{i}}
\end{gathered}
$$

$109 i=1, \ldots ., n$ is the total number of data points; the design strength profiles for all cases are

110 noted in Table 1. The clays have a sensitivity, $S_{\mathrm{t}}$, between 1.5 and 3.5, which are derived from

111 the remoulded tests on the cored samples.

112 For the sand layers, the relative densities were calculated based on blow counts from the

113 hammer sample. The blow counts from the offshore wireline thin-wall Shelby tube sampler 
114 were converted to an SPT $N_{60}$ (blows for $300 \mathrm{~mm}$ ) value by using a ratio of 1:2 (based on

115 local experience). The $N_{60}$ values were used to calculate the relative densities of the fine

116 sandy soils using the methods proposed by Terzaghi and Peck (1967), Skempton (1986) and

117 Kulhawy and Mayne (1990). The equations and derived average relative densities are listed in

118 Table 3, showing consistent estimation.

119 The friction and dilation angles were then determined using the general strength-dilatancy

120 framework established by Bolton (1986)

$$
I_{\mathrm{R}}=I_{\mathrm{D}}\left[10-\ln \left(p^{\prime}\right)\right]-1
$$

$\varphi^{\prime}=31+3 I_{\mathrm{R}}$

124 where $I_{\mathrm{D}}$ is the relative density of the sand; $I_{\mathrm{R}}$ is the dilatancy index, $p^{\prime}$ is the mean effective

125 stress, and $\phi^{\prime}$ and $\psi$ are the friction and dilation angles of the sand, respectively. The values 126 are summarised in Table 1.

\subsubsection{Details of spudcan foundations}

128 Two different types of spudcan geometry, hexagonal Marathon LeTourneau Design Class 82129 SDC (MLT 82-SDC) and dodecagonal Marathon LeTourneau Design Class 116-C (MLT 130 116-C), were used for the selected case histories. Figure 1 shows schematic diagrams of the 131 spudcans, and the (plan area) equivalent diameter, plan area, volume, lightship-plus-variable 132 load, maximum preload, and maximum bearing pressure (under the maximum preload) 133 applied during preloading and installation are presented in Table 2. The spudcan (plan area) 134 equivalent diameters, $D$, are 12.1 and $13.5 \mathrm{~m}$, and the bearing pressures range from 309.5 to 135 $390.0 \mathrm{kPa}$. 


\section{NUMERICAL ANALYSIS}

137

138

140

141

142

143

\subsection{Analysis Details}

Three-dimensional LDFE analyses were undertaken to simulate the continuous penetration of the spudcans into the seabed surface, providing a complete penetration resistance profile. Spudcan foundation shapes matching the real geometry (including cut-outs, see Figure 1) were considered. The analyses were performed using the Coupled Eulerian-Lagrangian (CEL) approach in the commercial FE package Abaqus/Explicit. The spudcan and soils were discretised using Lagrangian and Eulerian meshes, respectively. The Eulerian mesh was composed of eight-node linear hexahedral elements with reduced integration and hourglass control, while the Lagrangian mesh was composed of four-node linear tetrahedral elements. The Lagrangian elements that move through the Eulerian mesh and the penetration resistance are obtained through contact between the footing and soil materials. The Coulomb friction law was used to describe the frictional footing-sand contact, with the coefficient of friction equal to $\alpha \tan \phi_{\mathrm{cv}}$, where $\alpha$ is the footing roughness factor and $\phi_{\mathrm{cv}}$ is the constant-volume friction angle of the sand. Consistent with previous studies by Qiu and Grabe (2012) and Hu et al. (2015a), a roughness factor of $\alpha=0.5$ was adopted in the analyses.

The displacement-controlled mode was used to simulate the penetration of the footing into the sand-over-clay soil. The penetration velocity was specified as $0.2 \mathrm{~m} / \mathrm{s}$. The minimum element size and soil domain size were selected based on the convergence study reported by Hu et al. (2014b) to achieve adequate numerical accuracy and efficiency and avoid boundary effects. To reduce the computational cost, by taking advantage of the axial symmetry of the geometry of the problem, only a quarter of the domain was modelled. The spudcan penetration depth, $d$, is defined relative to the lowest point of the spudcan's largest cross-section. 


\subsection{Constitutive Models for Sand and Clay}

160 It was reasonably assumed that the spudcan penetration into sand was under drained 161 conditions and that into clay was under undrained conditions. A brief discussion of the 162 adopted constitutive models is given below, and the details can be found in Hu et al. (2015a) 163 and Hossain and Randolph (2009).

164 For the sand, the traditional Mohr-Coulomb model was modified by varying $\phi$ and $\psi$ with

165

166

167

168

169

170

171 respect to the accumulated plastic shear strain, $\xi$. The friction angle was assumed to increase linearly from an initial value $\phi_{\mathrm{ini}}$ to a peak value $\phi_{\mathrm{p}}$, before reducing linearly to $\phi_{\mathrm{cv}}$ when the critical state was approached. The peak friction angle $\phi_{\mathrm{p}}$ was calculated based on both the relative density, $I_{\mathrm{D}}$, and the mean effective stress applied on the soil, $p^{\prime}$, following Bolton's (1986) framework (Equations 4 6, with $\phi_{\mathrm{cv}}$ taken as $31^{\circ}$ ). The threshold plastic shear strains corresponding to $\phi_{\mathrm{p}}$ and $\phi_{\mathrm{cv}}$ are $\xi_{\mathrm{p}}=4 \%$ and $\xi_{\mathrm{cv}}=10 \%$, respectively. The incremental plastic shear strain during each incremental step was calculated as

$$
\Delta \xi=\frac{\sqrt{6\left[\left(\Delta \varepsilon_{1}-\Delta \varepsilon_{2}\right)^{2}+\left(\Delta \varepsilon_{2}-\Delta \varepsilon_{3}\right)^{2}+\left(\Delta \varepsilon_{3}-\Delta \varepsilon_{1}\right)^{2}\right]}}{3}
$$

where $\Delta \varepsilon_{1}, \Delta \varepsilon_{2}$ and $\Delta \varepsilon_{3}$ are the incremental principal plastic strains measured from the start to the end of the current step. The friction and dilation angles at each integration point are updated for the next step according to the magnitude of deviatoric plastic strain.

The clay was modelled as a linear elastic-perfectly plastic material obeying the Tresca yield criterion, but extended based on the proposed model of Einav and Randolph (2005) and Zhou and Randolph (2007), the Tresca soil model was extended, taking the combined effects of the rate dependency and gradual softening into account. According to the average rate of maximum shear strain in the previous increments and the current accumulated absolute plastic 
181

182

183

184

185

186

187

188

189

190

191

192

193

194

195

shear strain, the undrained shear strength at individual Gauss points was modified to

$$
S_{\mathrm{u}}=\left[1+\mu \log \left(\frac{\operatorname{Max}\left(|\dot{\xi}|, \dot{\xi}_{\text {ref }}\right)}{\dot{\xi}_{\text {ref }}}\right)\right]\left[\delta_{\text {rem }}+\left(1-\delta_{\text {rem }}\right) \mathrm{e}^{-3 \xi / \xi_{95}}\right] s_{\text {ui }}
$$

where $s_{\mathrm{ui}}$ is the undrained shear strength derived from the boring sample. The first bracketed term augments the strength according to the maximum strain rate, $\dot{\xi}$, relative to a reference value, $\dot{\xi}_{\text {ref }}$. Consistent with the triaxial tests in Erbrich (2005) and Lunne et al. (2006), $\dot{\xi}_{\text {ref }}$ was considered as $1 \% / \mathrm{h}$. For a circular spudcan foundation, the rate parameter $\mu$ was taken as 0.1 (Low et al. 2008). The degradation of strength was modelled in the second part of Equation 8 according to an exponential function of the cumulative shear strain, $\xi$, from the intact condition to a fully remoulded ratio, $\delta_{\text {rem }}\left(=1 / S_{\mathrm{t}}\right)$. The parameter $\xi_{95}$ is used to control the relative ductility, representing the cumulative shear strain required for 95\% remoulding. Following Randolph (2004), Hossain and Randolph (2009) and Hossain et al. (2015), a typical value of $\xi_{95}=15$ was considered in this analysis. All the analyses simulated undrained conditions, and a Poisson's ratio of $v=0.49$ was adopted. A uniform stiffness ratio of $E / s_{u}=$ 500 (where $E$ is the Young's modulus) was taken throughout the clay profile.

Considering the symmetry of the problem, only a quarter spudcan and soil were modelled. The radius and height of the soil domain were 3.25D and 5.0D (as obtained from preliminary convergence study; Hu et al. 2015a), respectively, to ensure that the soil extensions are sufficiently large to avoid boundary effect. A very fine soil mesh was necessary to capture the spudcan-soil contact accurately. Based on the mesh convergence study from Hu et al. (2015a), the typical soil element size along the trajectory of the spudcan was adopted as $0.025 D$. 


\section{ANALYTICAL APPROACHES}

202

203

204

205

206

207

208

209

210

211

212

213

214

215

216

217

\subsection{Methods}

In this study, the two main ISO methods, (a) the load spread method (Terzaghi and Peck 1948; ISO, 2012) and (b) the punching shear method (Hanna and Meyerhof 1980; ISO, 2012), and one mechanism-based design approach (Hu et al. 2015a, 2017, 2018) were considered. These methods are discussed briefly below with the full details tabulated in Appendix.

\subsubsection{ISO methods}

In the load spread method recommended in the ISO guidelines, the bearing capacity of a spudcan, $Q_{\mathrm{v}}$, is calculated by considering a fictitious footing at the interface between the sand and clay layers according to

$$
Q_{\mathrm{v}}=Q_{\mathrm{u}, \mathrm{b}}-0.25 \pi\left(D+2 \frac{t}{n_{\mathrm{s}}}\right)^{2} t \gamma_{\mathrm{s}}^{\prime}
$$

where $t$ is the thickness of the sand layer below the spudcan, $n_{\mathrm{s}}$ is the load spread ratio, and $\gamma_{\mathrm{s}}^{\prime}$ is the effective unit weight of sand. The recommended values of the load spread factor $n_{\mathrm{s}}$ are 3 to 5 though lower value was suggested based on actual spudcan penetration data (Baglioni et al. 1982). $Q_{\mathrm{u}, \mathrm{b}}$ is the ultimate vertical foundation bearing capacity for the fictitious footing at the interface between the sand and clay layers with no backfill, which can be calculated as

$$
Q_{\mathrm{u}, \mathrm{b}}=s_{\mathrm{u}} N_{\mathrm{c}} 0.25 \pi\left(D+2 \frac{t}{n_{\mathrm{s}}}\right)^{2}+\gamma_{\mathrm{s}}^{\prime}\left[0.25 \pi\left(D+2 \frac{t}{n_{\mathrm{s}}}\right)^{2} H_{\mathrm{s}}+V_{\mathrm{b}}\right]
$$

where $V_{\mathrm{b}}$ is the spudcan volume below the base level. The values of the bearing capacity factor $N_{\mathrm{c}}$ tabulated by Houlsby and Martin (2003) and recommended by the ISO (2012) were used. 
221

222

223

224

225

226

227

228

229

230

231

232

233

234

235

The second term of Equation 9 is the weight of the sand plug between the spudcan base and the original sand-clay layer interface.

In the ISO punching shear method, the bearing capacity of a spudcan, $Q_{\mathrm{v}}$, is calculated assuming a cylindrical failure plane in the sand layer between the base of the foundation and the original sand-clay layer interface (i.e., considering a dilation angle $\psi=0$ ). The frictional resistance on the vertical surface of the failure plane and the clay bearing capacity at the base were mobilised, and the bearing capacity was expressed as

$$
Q_{\mathrm{v}}=Q_{\mathrm{u}, \mathrm{b}}-0.25 \pi D^{2} t \gamma_{\mathrm{s}}^{\prime}+0.5 \pi D^{2} t\left[t \gamma_{\mathrm{s}}^{\prime}+2 \gamma_{\mathrm{s}}^{\prime}\left(H_{\mathrm{s}}-t\right)\right] \frac{K_{\mathrm{s}} \tan \phi^{\prime}}{D}
$$

with

$$
Q_{\mathrm{u}, \mathrm{b}}=s_{\mathrm{u}} N_{\mathrm{c}}\left(0.25 \pi D^{2}\right)+\gamma_{\mathrm{s}}^{\prime}\left(0.25 \pi D^{2} H_{\mathrm{s}}+V_{\mathrm{b}}\right)
$$

where $K_{\mathrm{s}}$ is the punching shear coefficient, which depends on the strength of both the sand layer and clay layer. It is suggested that the value of this coefficient be obtained from a chart improved from Hanna and Meyerhof (1980).

\subsubsection{Hu et al. design approach}

Hu et al. (2015a, 2017, 2018) proposed a 'mechanism-based' design approach based on the soil flow mechanisms observed in model tests and LDFE analyses. The Hu et al. approach simplified the spudcan penetration profile as a combination of the peak resistance and postpeak resistance in the sand layer, $q_{\text {peak }}$ and $q_{\text {post-peak }}$ and the resistance in the clay layer, $q_{\text {clay }}$. $q_{\text {peak }}$ is the sum of the frictional resistance in the sand, the bearing capacity of the underlying clay and the weight of the sand frustum, and it is expressed as 


$$
\begin{aligned}
& q_{\text {peak }}=\left(N_{\mathrm{c} 0} s_{\mathrm{um}}+q_{0}+0.12 \gamma_{\mathrm{s}}^{\prime} H_{\mathrm{s}}\right)\left(1+\frac{1.76 H_{\mathrm{s}}}{D} \tan \psi\right)^{E^{*}} \\
& +\frac{\gamma_{\mathrm{s}}^{\prime} D}{2 \tan \psi\left(E^{*}+1\right)}\left[1-\left(1-\frac{1.76 H_{\mathrm{s}}}{D} E^{*} \tan \psi\right)\left(1+\frac{1.76 H_{\mathrm{s}}}{D} \tan \psi\right)^{E^{*}}\right]
\end{aligned}
$$

where $N_{\mathrm{c} 0}$ is the bearing capacity factor for clay at the base of a circular foundation, which is obtained from Houlsby and Martin (2003); $q_{0}$ is the effective overburden pressure; $E^{*}$ is a parameter to simplify the algebra. The depth of the peak resistance in the sand layer is taken as $0.12 H_{\mathrm{s}}$, where $H_{\mathrm{s}}$ is the sand layer thickness.

For assessing spudcan penetration resistance after the peak failure in the top sand layer and before penetrating into the bottom clay layer, an analytical model was proposed as

$$
q=\frac{\gamma_{\mathrm{s}}^{\prime} D}{E}+\left\{\begin{array}{l}
{\left[\left(14.8 \frac{d-0.1 H_{\mathrm{s}}}{D}+10.6\right) \mathrm{Sum}+q_{0}+\gamma_{\mathrm{s}}^{\prime} H_{\mathrm{s}}+\left(\gamma_{\mathrm{c}^{\prime}}-\gamma_{\mathrm{s}}^{\prime}\right)\left(d-0.1 H_{\mathrm{s}}\right)-\frac{\gamma_{\mathrm{s}}^{\prime} D}{E}\right]} \\
\exp \left[\frac{E\left(H_{\mathrm{s}}-d\right)}{D}\right]
\end{array}\right\}
$$

where $\gamma^{\prime}{ }_{c}$ is the effective unit weight of clay and $E$ is also a parameter to simplify the algebra (Hu et al. 2018).

For the resistance in the clay layer, the bearing capacity is expressed as

$$
q_{\text {clay }}=N_{\mathrm{c}} s_{\mathrm{u} 0}+H_{\text {plug }} \gamma_{\mathrm{c}}^{\prime}=N_{\mathrm{c}} s_{\mathrm{u} 0}+0.9 H_{\mathrm{s}} \gamma_{\mathrm{c}}^{\prime} \quad\left(0.16 \leq \frac{H_{\mathrm{s}}}{D} \leq 1.00\right)
$$

where $s_{\mathrm{u} 0}$ is the clay shear strength at the lowest level of the spudcan's widest cross-sectional area and $H_{\text {plug }}$ is the height of the sand plug. The bearing capacity factor $N_{\mathrm{c}}$ was summarised from a sand overlying clay centrifuge testing database and LDFE analyses of the full penetration process, incorporating various footing shapes and soil conditions.

The jack-up operators need to understand not only at what load punch-through will occur but 
also the depth of penetration during a punch-through event for assessing the consequences of a punch-through failure. The punch-through distance is such an indicator, and it is evaluated as the distance from the depth of $q_{\text {peak }}$ to the depth where $q_{\text {clay }}$ equals $q_{\text {peak }}$ in the underlying clay layer (where equilibrium is re-established) although, in the field, the distance may be controlled by hull buoyancy, which essentially limits the movement of the leg and spudcan. It was used as a basic indicator of the severity of a potential punch-through failure. More details of the equations can be found in Hu et al. (2015b).

\section{RESULTS AND DISCUSSION}

\subsection{Comparison among Measured Field Data, Estimation and LDFE Results}

Figures 2 to 6 plot the reported spudcan penetration data for Sites 1 5 (Tables 1 and 2), estimations obtained using the design methods, and the results from the 3D LDFE analyses. For the ISO (2012) design methods, the estimations from the load spread method with $n_{\mathrm{s}}$ values of 3 and 5 were made and are presented together with those from the punching shear method. The ISO guideline recommends the use of the expression for $N_{\mathrm{c}}$ given in Houlsby and Martin (2003), so it was adopted for the bearing capacity calculations in the underlying clay layer. For the Houlsby and Martin method, the local shear strength $s_{\mathrm{u} 0}$ and expressions for the $N_{\mathrm{c}}$ factor considering $\alpha=0.4$ (as suggested in SNAME, 2008) were used. For Sites 15, the undrained shear strength from the statistical method was used in the predictions and LDFE simulations. As there is a large scatter in the soil strength data for Site 5, and only limited data in 3 metres of clay directly under the sand layer, a weighted average method was also used to derive the shear strength and additional estimation and simulation were made based on this relationship. The following overall comments were obtained by comparing the vertical bearing capacity profiles from field measurements, estimations from design methods and LDFE simulations. 
(a) The ISO methods provide good predictions for both the load-penetration profile and punch-through distance for Site 4 but an underprediction of the peak bearing capacity in the remainder. The methods give a reasonably good predictions of punch-through distance for Sites 1 and 5. However, the bearing capacity for Site 2 is significantly under-predicted. For Site 3, a severe punch-through failure is estimated, but a safe installation, with the spudcans rested in the sand layer, was observed in the field.

(b) The load-penetration profiles predicted using the Hu et al. approach fit the measured profiles for underlying relatively soft clay (i.e., Sites 1, 2, 3 and 5 (weighted average method)) but the approach overestimates the profiles with underlying stiff clay (i.e., Sites 4 and 5 (statistical average method)).

(c) For Sites 1, 2 and 5 (weighted average method), under the final preload, the spudcan punch-through potential is estimated by the $\mathrm{Hu}$ et al. approach reasonably well. However, under the preload, no punch-through is estimated for Sites 3, 4 and 5 (statistical average method). For the first case, this conclusion is consistent with field observations, while for the last two cases, the reason is the overestimation of both $q_{\text {peak }}$ and $q_{\text {clay. }}$

(d) For each field case, the load-penetration profiles calculated using the load spread and punching shear method in the ISO (2012) guideline provide a lower bound estimate of the bearing capacity, while the Hu et al. approach provides a higher estimate of the bearing capacity.

(e) The load-penetration profiles calculated using the Hu et al. approach are generally consistent with the computed curves from the LDFE analyses, though with some discrepancies.

With respect to the measured, estimated and computed profiles for each site, further detailed 
(a) Site 1 (Figure 2): The seabed consisted of four-layer sand and clay soils. The sands were in a loose state, with a relative density of $22.7 \%$ and $24.4 \%$ for the first and second layers, respectively. Olive grey clay with $s_{\mathrm{um}} / \gamma^{\prime} D=0.18$ (first clay layer) and 0.19 (second clay layer) and $k D / s_{\text {um }}=-0.27$ (first clay layer) and 0.99 (second clay layer) formed the second and fourth layers (Figure 2a). The measured load-penetration profiles somewhat increased with depth, and the spudcans finally rested at a deep penetration of $d=15 \sim 21 \mathrm{~m}$ (Figure $2 \mathrm{~b}$ ). A leg run of $10.5 \mathrm{~m}$ to $13 \mathrm{~m}$ occurred to the port leg and, under the final preload of $35.5 \mathrm{MN}$, a settlement of $18.5 \mathrm{~m}$ to $21 \mathrm{~m}$ occurred to the bow leg. The estimated profiles using both the ISO methods and the Hu et al. approach show potential of a severe punch-through failure in the second sand layer. However, the estimated profile from the Hu et al. approach match the measured one in the $2^{\text {nd }}$ sand layer. In the $2^{\text {nd }}$ clay layer, the ISO methods significantly underestimate the penetration resistance except the final penetration depths of the starboard and bow legs. The Hu et al. approach provides reasonable estimates up to $12.5 \mathrm{~m}$ followed by overestimates except the final penetration depth of the port leg. The bearing capacity-depth profile from the LDFE analysis shows a trend similar to that of the estimated profile using the Hu et al. approach in all four soil layers.

(b) Site 2 (Figure 3): The seabed consisted of medium sand overlying soft clay with $s_{\mathrm{um}} / \gamma^{\prime} D=0.20$ and $k D / s_{\mathrm{um}}=0.99$ (Figure 3a). A number of consistent strength data points led to derive a more accurate strength profile for the clay layer. Under the maximum preload of 53.4 MN, all three legs experienced a severe punch-through with the punch-through distance measured as 15.76 18.50 m (Figure 3b). The spudcans finally rested at $d=15.8 \sim 18.5 \mathrm{~m}$. Although the potential for punch-through failure is estimated by the ISO methods and the final penetration depths are well estimated, both 
the peak bearing capacity in the sand layer and the bearing capacity in the clay layer are significantly underestimated. The Hu et al. approach estimates the magnitude and depth of the peak bearing capacity in the sand layer reasonable well, with the difference in terms of the peak bearing capacity being $12 \%$. The punch-through distance is estimated as $10.92 \mathrm{~m}$, which is lower than that obtained from the field measurements. The penetration resistance in the clay layer is significantly overestimated. The computed profile from the LDFE simulation shows almost constant bearing capacity in the top sand layer, which is consistent with the field data. However, it follows the estimated profile using the $\mathrm{Hu}$ et al. approach in the clay layer. This comparison highlights that a significant number of data points led more accurate clay strength profile improves the estimation accuracy of the Hu et al. approach.

(c) Site 3 (Figure 4): The seabed consisted of medium sand $\left(I_{\mathrm{D}}=63.7 \%\right)$ overlying soft clay with $s_{\mathrm{um}} / \gamma^{\prime} D=0.25$ and $k D / s_{\mathrm{um}}=0.51$ (Figure 4a). This is the only case in which three spudcans rested in the sand layer with no punch-through failure. The measured bearing capacity-depth profiles for the bow leg and starboard leg were similar. The profile for the port leg followed the same trend, although with a slightly greater penetration of $1.6 \mathrm{~m}$, which may be due to the movement of the seabed sand around by currents. The final embedment was $d=1 \sim 1.6 \mathrm{~m}$, which was near the sand layer surface (Figure 4b). Under a preload of 35.6 MN, the ISO methods estimate severe punch-through failure immediately after the spudcans penetrate into the sand layer, and the spudcan would penetrate rapidly until the final penetration depth of $15.84 \mathrm{~m}$ to balance the maximum preload. The $\mathrm{Hu}$ et al. approach estimates a peak bearing capacity of 46.6 MN, which indicates that the soil bearing resistance (mainly from the sand in this case) is high enough to resist the preload, and no punch-through failure 
would occur. The LDFE analysis again confirms this conclusion by simulating similar trends in both the top sand and the underlying clay layer.

(d) Site 4 (Figure 5): The seabed consisted of very dense sand overlying stiff clay with higher $s_{\text {um }} / \gamma^{\prime} D$ of 0.42 and $k D / s_{\text {um }}$ of 2.06 (Figure 5a) compared to those relatively soft clays at Sites 1 3. Only the Bow leg experienced a punch-through failure from 3.5 to $6.92 \mathrm{~m}$. The other two legs penetration were limited to a shallow depth of $d=3.9 \sim 6.9$ m (Figure 5b). The profiles using the ISO methods provide reasonable estimation of the measured data. The Hu et al. approach overestimates the bearing capacity, and no punch-through failure is estimated under the current preload of 56.0 MN. The reason might be that the peak bearing capacity expression in the $\mathrm{Hu}$ et al. approach was mainly based on a database of relatively soft underlying clay, and the high shear strength of the clay (with a gradient of $5.71 \mathrm{kPa} / \mathrm{m}$ ) at this site was beyond the range over which it was originally calibrated. Additionally, only two types of laboratory tests (with 14 data points) were used for deriving the shear strength of the soil, and, as discussed previously, the prediction is sensitive to the quality of the shear strength data. The LDFE analysis also estimates a much higher bearing capacity, but no punchthrough failure potential is shown.

(e) Site 5 (Figure 6): The seabed consisted of medium sand over soft clay with $s_{\mathrm{um}} / \gamma^{\prime} D=$ 0.21 and $\mathrm{kD} / \mathrm{s}_{\mathrm{um}}=1.71$ (Figure 6a). Under a preload of $V_{\mathrm{p}}=35.6 \mathrm{MN}$, the final spudcans embedment depth were in the range of $d=7.4 \sim 8.6 \mathrm{~m}$ (Figure 6b). All three legs experienced a severe punch-through at a depth of $0.5 \sim 1.8 \mathrm{~m}$. The ISO methods provide good estimate of the load-penetration profiles for $d / D=0 \sim 0.71$, including the peak capacities at punch-through in the sand layer and most of the penetration in the clay layer. In addition, the final penetration depths are well estimated. The Hu et al. approach with clay strength derived from the statistical average method, however, 
significantly overestimates the bearing capacity in both sand and clay layers. The reason might be the scattered clay strength data in this site with the obvious discrepancy between the average shear strength profile and the site investigation data being particularly in the top $7 \mathrm{~m}$ (see Figure 6a). There are less data points in the top and middle parts of the boring log compared to the bottom part, so in another comparison more weight was assigned to the data points of the top $7 \mathrm{~m}$. The Hu et al. approach using this weighted average strength profile provides improved estimation in the sand layer including the peak capacity at punch-through. This comparison highlights the importance of adequate data, leading to a more accurate soil strength profile. The computed profile from the LDFE simulation using the weighted average shear strength shows somewhat increasing resistance with depth.

\subsection{Lessons Learnt}

(a) The quality of the data in the interested depth range is necessary for the accurate estimation of the shear strength of the soil and then the estimation of the bearing capacity-depth profile. The predictions are sensitive to the quality of the site investigation data, with few and scattered data possibly worsening the estimations, as shown for Sites 1, 4 and 5.

(b) The load spread method with a load spread ratio of $n_{\mathrm{s}}=3$ always estimates a higher bearing capacity than that with a load spread ratio of $n_{\mathrm{s}}=5$, and the estimated profile lies closer to the field measurements. As such, it is recommended that $n_{\mathrm{s}}=3$ be adopted for predicting spudcan penetration resistance, at least for locations in the Gulf of Mexico. This is consistent with the observation of Hu et al. (2015b) that $1.73 \leq n_{\mathrm{s}} \leq$ 2.75 best fits the field data. 
(c) To reduce the subjectivity in the selection of the parameters needed for the bearing capacity analysis, more high quality soil information is better. The volume of information and its reliability may be increased by additional in situ testing and soil borings at each spudcan location and advanced laboratory soil tests that identify and reduce the data scattering and the effects of sample disturbances (Menzies and Roper

(d) Site 2 and Site 3 are located in the same $4.83 \times 4.83 \mathrm{~km}$ block. Yet, for site 2 , all three spudcans experienced a punch-through and penetrated through the top sand layer while for site 3, all three spudcans rested in the top sand layer although relatively the top sand layer is thinner (7 m for site 2 vs $4.9 \mathrm{~m}$ for site 3; relative density similar; Table 1 ) and the underlying clay layer is slightly stronger ( $s_{\mathrm{um}}=17.87 \mathrm{vs} 22.13 \mathrm{kPa}$; Table 1). This is chiefly because, as learned from site 3, the applied maximum bearing pressure (under the full preload) has been reduced to of $310.4 \mathrm{kPa}$ for site 3 (from $371.9 \mathrm{kPa}$ at site 2). Otherwise, from Figure 4b, an application of a similar bearing pressure of $371.9 \mathrm{kPa}$ ( $>\sim 42 \mathrm{MN}$ full preload) would have resulted in a severe punchthrough. The reverse could have been true as well, as relying on the experience of site 3 and without site-specific investigation and prediction, it would have been thought that a pressure of $371.9 \mathrm{kPa}$ could also be applied safely at site 2 .

A disastrous consequence of this principle is the punch-through event experienced by the Harvey H. Ward jack-up rig at Anding, offshore of the Malaysian peninsula west coast (Maung and Ahmad 2000). Prior to the installation, the load-penetration resistance was predicted using previously obtained borehole data for another jack-up rig (Trident 17) for the same location showing no existence of an interbedded soft layer. Trident 17 was deployed at Anding without any problem for a maximum preload of $37 \mathrm{MN}$ (bearing pressure of $375 \mathrm{kPa}$ ) and provided confidence for further 
jack-up installations. Unfortunately, the installation of the Harvey H. Ward rig in 1999 under a maximum preload of 39.5 MN (an equivalent pressure of $344 \mathrm{kPa}$, lower than that of Trident 17) did not proceed as well. The bow leg punched through at $11 \mathrm{~m}$, which caused the hull to tilt and resulted in bending damage to all three legs. Subsequently, additional soil borings were carried out, and a careful analysis of the data identified a soft clay layer at 13.5 to $17 \mathrm{~m}$ under a thin stiff layer at 11 to $13.5 \mathrm{~m}$.

\section{CONCLUDING REMARKS}

Three different methods for estimating the penetration resistance of spudcans in sand

overlying clay soils have been compared with high-quality data from field installations. A brief summary was provided about three design methods, comprising the two ISO (2012) methods and the mechanism-based design approach of Hu et al. (2015a, 2017, 2018). Five case histories were considered, all from different locations in the Gulf of Mexico, where the soils were relatively homogeneous, predominantly sand on top of normally to lightly over-

442 consolidated clay with the strength increasing essentially linearly with depth. The data for 443 spudcan penetrations from 0 to 1.7 diameters were compared with the estimations from the 444 design methods and with the results from three-dimensional large deformation finite element 445 (LDFE) analyses.

446 Where more and higher quality site investigation data were available, the estimations using 447 the Hu et al. approach were found to be in agreement with the measured bearing capacity448 depth profiles. The profiles estimated using the ISO methods provided (i) lower bound 449 estimates of the bearing capacity of the soils and upper bounds of the spudcan penetration 450 depth, and (ii) the good estimation of the measured data where the site investigation data are 451 less and scattered. 


\section{ACKNOWLEDGEMENTS}

453 The research presented herein was undertaken in collaboration with Fugro-McClelland 454 Marine Geosciences, Inc., Houston, Texas; and with support from the Australian Research 455 Council (ARC) through the Linkage Project LP140100066. This work forms part of the 456 activities of the Centre for Offshore Foundation Systems (COFS), currently supported as a 457 node of the Australian Research Council Centre of Excellence for Geotechnical Science and 458 Engineering and as a Centre of Excellence by the Lloyd's Register Foundation. The Lloyd's 459 Register Foundation supports the advancement of engineering-related education, and funds 460 research and development that enhances safety of life at sea, on land and in the air. This 461 support is gratefully acknowledged. 


\section{REFERENCES}

463

464

465

466

467

468

469

470

471

472

473

474

475

476

477

478

479

480

481

482

483

484

485

486

487

488

Baglioni, V. P., Chow, G. S., and Endley, S. N. (1982). “Jack-up foundation stability in stratified soil profiles.” Proc., 14th Offshore Technology Conf., Houston, OTC 4409.

Bolton, M. D. (1986). “The strength and dilatancy of sands.” Géotechnique, 36(1), 65-78.

Cassidy, M. J., Li, J. H., Hu, P., Uzielli, M., and Lacasse, S. (2015). “Deterministic and probabilistic advances in the analysis of spudcan behaviour.” Proc. 3rd Int. Sym. on Frontiers of Offshore Geotechnics. (ISFOG-2015), Oslo, Norway. Vol. 1, pp. 183-214.

Craig, W. H., and Chua, K. (1990). "Deep penetration of spud-can foundation on sand and clay." Géotechnique, 40(4), 541-556.

Einav, I., and Randolph, M. F. (2005). “Combining upper bound and strain path methods for evaluating penetration resistance.” Int. J. Numerical Methods in Engineering, 63(14), 1991-2016.

Erbrich, C. T. (2005). “Australian frontiers - spudcans on the edge.” Proc. 1st Int. Symp. on Frontiers in Offshore Geotechnics. (ISFOG-2005), Perth, pp. 49-74.

Hanna, A. M., and Meyerhof, G. G. (1980). "Design charts for ultimate bearing capacity of foundations on sand overlying soft clay.” Can. Geotech. J., 17(2), 300-303.

Hossain, M. S. (2014). "Experimental investigation of spudcan penetration in multi-layer clays with interbedded sand layers.” Géotechnique, 64(4), 258-277.

Hossain, M. S., and Randolph, M. F. (2009). "Effect of strain rate and strain softening on the penetration resistance of spudcan foundations on clay.” Int. J. Geomechanics, 9 (3), 122-132.

Hossain, M. S., and Randolph, M. F. (2012). "Spudcan foundations on multi-layered soils with interbedded sand and stiff clay layers.” Int. J. Offshore and Polar Engineering, 22 (3), 248-255.

Hossain, M. S., Zheng, J., Menzies, D., Lillian, M., and Randolph, M. F. (2014). "Spudcan penetration analysis for case histories in clay.” J. Geotech. Geoenviron. Engng., 140 (7), 04014034-1-13. 
Houlsby, G. T., and Martin, C. M. (2003). "Undrained bearing capacity factors for conical footings on clay.” Géotechnique, 53(5), 513-520.

Hu, P., Stanier, S. A., Cassidy, M. J., and Wang, D. (2014a). "Predicting peak resistance of spudcan penetrating sand overlying clay.” J. Geotech. Geoenviron. Engng., 140(2), 04013009-1-12.

Hu, P., Wang, D., Cassidy, M. J., and Stanier, S. A. (2014b). "Predicting the resistance profile of spudcan on sand overlying clay.” Can. Geotech. J., 51(10), 1151-1164.

Hu, P., Wang, D., Stanier, S. A., and Cassidy, M. J. (2015a). “Assessing the punch-through hazard of a spudcan on sand overlying clay.” Géotechnique, 65(11), 883-896.

Hu, P., Stanier, S. A., Wang, D., and Cassidy, M. J. (2015b). “A comparison of full profile prediction methods for a spudcan penetrating sand overlying clay.” Geotech. Lett., 5 (3), 131-139.

Hu, P., Stanier, S. A., Wang, D., and Cassidy, M. J. (2016). "Effect of footing shape on penetration in sand overlying clay.” Int. J. Phys. Model. Geo., 16(3), 119-133.

Hu, P., and Cassidy, M. J. (2017). "Predicting jack-up spudcan installation in sand overlying stiff clay.” Ocean. Eng., 146, 246-256.

Hu, P., Cassidy, M. J., and Randolph, M. F. (2018). "Bearing capacity on sand overlying clay: An analytical model for predicting post peak behaviour.” Mar. Struct., 59, 94-104.

InSafeJIP (2011). Improved guidelines for the prediction of geotechnical performance of spudcan foundations during installation and removal of jack-up units. Joint Industry Funded Project.

ISO (2012). Petroleum and natural gas industries - Site specific assessment of mobile offshore units - Part 1: Jack-ups. International Organization for Standardization, ISO 19905-1.

Jack, R. L., Hoyle, M. J. R., Smith, N. P., and Hunt, R. J. (2013). “Jack-up accident statistics - a further update.” Proc., 14th Int. Conf. on the Jack-up Platform Design, Construction and Operation, London.

Lacasse, M., Nadim, F., Rahim, A., and Guttormsen, T. R. (2007). "Statistical description of characteristic soil properties.” Proc. Offshore Technology Conf., Houston, OTC 19117. 
Lee, K. K., Randolph, M. F., and Cassidy, M. J. (2009). "New simplified conceptual model for spudcan foundations on sand overlying clay soils.” Proc. Offshore Technology Conf., Houston, OTC 20012.

Lee, K. K., Cassidy, M. J., and Randolph, M. F. (2013a). “Bearing capacity on sand overlying clay soils: Experimental and finite element investigation of potential punch-through failure.” Géotechnique, 63(15), 1271-1284.

Lee, K. K., Randolph, M. F., and Cassidy, M. J. (2013b). "Bearing capacity on sand overlying clay soils: A simplified conceptual model.” Géotechnique, 63(15), 1285-1297.

Low, H. E., Randolph, M. F., DeJong, J. T., and Yafrate, N. J. (2008). "Variable rate full-flow penetration tests in intact and remoulded soil.” Proc. 3rd Int. Conf. on Geotechnical and Geophysical Site Characterization, Taylor \& Francis Group, Taipei, Taiwan, pp. 10871092.

Lunne, T., Berre, T., Andersen, K. H., Strandvik, S., and Sjursen, M. (2006). "Effects of sample disturbance and consolidation procedures on measured shear strength of soft marine Norwegian clays.” Can. Geotech. J., 43(7), 726-750.

Maung, U. M., and Ahmad, C. K. M. (2000). "Swiss cheesing to bring in a jack-up rig at Anding location.” Proc. IADC/SPE Asia Pacific Drilling Technology Conf., Kuala Lumpur, Malaysia. Asia Pacific Drilling Technology, Richardson, Tex. Paper IADC/SPE 62755.

Menzies, D., and Lopez, C. R. (2011). “Four atypical jack-up rig foundation case histories.” Proc. 13th Int. Conf. The Jack-up Platform: Design, Construction and Operation, London.

Osborne, J. J., Houlsby, G. T., Teh, K. L., Bienen, B., Cassidy, M. J., Randolph, M. F., and Leung, C. F. (2009). "Improved guidelines for the prediction of geotechnical performance of spudcan foundations during installation and removal of jack-up units.” Proc., Offshore Technology Conf., Houston, OTC 20291.

Osborne, J. J., and Paisley, J. M. (2002). “SE Asia jack-up punch-throughs: The way forward?” Proc., the Int. Conf. on Offshore Site Investigation and Geotechnics Sustainability and Diversity. London, UK, pp. 301-306. 
Qiu, G., and Henke, S. (2011). “Controlled installation of spudcan foundations on loose sand overlying weak clay.” Marine Structures, 24(4), 528-550.

Qiu, G., and Grabe, J. (2012). "Numerical investigation of bearing capacity due to spudcan penetration in sand overlying clay.” Can. Geotech. J., 49(12), 1393-1407.

Randolph, M. F. (2004). "Characterisation of soft sediments for offshore applications. Keynote lecture.” Proc. 2nd Int. Conf. Site Characterisation, Porto 1, 209-231.

Skempton, A. K. (1986). "Standard penetration test procedures and the effects in sands of overburden pressure, relative density, particle size, aging, and overconsolidation.” Géotechnique, 36(3), 425-447.

SNAME (2008). Guidelines for site specific assessment of mobile jack-up units, T\&R Bulletin 5-5 and 5-5A, panes OC-7 site assessment of jack-up rigs. Jersey City, NJ, USA: Society of Naval Architects and Marine Engineers.

Teh, K. L., Cassidy, M. J., Leung, C. F., Chow, Y. K., Randolph, M. F., and Quah, M. (2008). "Revealing the bearing capacity mechanisms of a penetrating spudcan through sand overlying clay.” Géotechnique, 58(10), 793-804.

Teh, K. L., Leung, C. F., Chow, Y. K., and Handidjaja, P. (2009). "Prediction of punchthrough for spudcan penetration in sand overlying clay.” Proc. Offshore Technology Conf., Houston, OTC 20060.

Teh, K. L., Leung, C. F., Chow, Y. K., and Cassidy, M. J. (2010). “Centrifuge model study of spudcan penetration in sand overlying clay.” Géotechnique, 60(11), 825-842.

Terzaghi, K., and Peck, R. B. (1948). “Soil Mechanics in engineering practice.” John Wiley and Sons, New York.

Tho, K. K., Leung, C. F., Chow, Y. K., and Swaddiwudhipong, S. (2012). "Eulerian finite element technique for analysis of jack-up spudcan penetration.” Int. J. Geomech., 12(1), 64-73.

Ullah, S. N., Stanier, S., Hu, Y., and White, D. (2017a). "Foundation punch-through in clay with sand: analytical modelling.” Géotechnique, 67(8), 672-690.

Ullah, S. N., Stanier, S., Hu, Y., and White, D. (2017b). "Foundation punch-through in clay with sand: centrifuge modelling.” Géotechnique, 67(10), 870-889. 
576 Zhou, H., and Randolph, M. F. (2007). "Computational techniques and shear band 577 development for cylindrical and spherical penetrometers in strain-softening clay.” Int. J. 578 Geomech., 7(4), 287-295.

579 


\begin{tabular}{|c|c|c|}
\hline 581 & $A$ & spudcan plan area at largest section \\
\hline 582 & $d$ & penetration depth of spudcan base (lowest point of largest section) \\
\hline 583 & $D$ & foundation plan area equivalent diameter \\
\hline 584 & E & Young's modulus \\
\hline 585 & $E^{*}$ & parameter to simplify the algebra \\
\hline 586 & $H_{\mathrm{s}}$ & sand layer thickness \\
\hline 587 & $I_{\mathrm{D}}$ & relative density of sand \\
\hline 588 & $I_{\mathrm{R}}$ & dilatancy index \\
\hline 589 & $k$ & rate of increase of undrained strength with depth \\
\hline 590 & $K_{\mathrm{s}}$ & punching shear coefficient \\
\hline 591 & $n$ & load spread ratio \\
\hline 592 & $N_{\mathrm{c}}$ & bearing capacity factor \\
\hline 593 & $N_{\mathrm{c} 0}$ & bearing capacity factor of clay at base level of a circular foundation \\
\hline 594 & $p^{\prime}$ & mean effective stress \\
\hline 595 & $q_{0}$ & effective overburden pressure \\
\hline 596 & $q_{\text {clay }}$ & penetration resistance in the clay layer \\
\hline 597 & $q_{\max }$ & maximum bearing pressure \\
\hline 598 & $q_{\text {peak }}$ & peak resistance in the sand layer \\
\hline 599 & $Q_{u b}$ & ultimate vertical bearing capacity of the fictitious footing \\
\hline 600 & $Q_{v}$ & vertical bearing capacity of a spudcan \\
\hline 601 & $S_{\mathrm{t}}$ & soil sensitivity \\
\hline 602 & $S_{\mathrm{u}}$ & undrained shear strength \\
\hline 603 & $s_{\mathrm{ui}}$ & undrained shear strength derived from the boring sample \\
\hline 604 & $S_{\mathrm{um}}$ & undrained shear strength at the sand-clay interface \\
\hline 605 & $s_{\mathrm{u} 0}$ & local undrained shear strength at spudcan base level, $d$ \\
\hline 606 & $t$ & thickness of the sand layer (below spudcan diameter) in the ISO methods \\
\hline 607 & $V$ & total volume of spudcan beneath backfill (buried volume) \\
\hline 608 & $V_{\mathrm{b}}$ & volume of spudcan below maximum bearing area \\
\hline 609 & $V_{\mathrm{P}}$ & final preload \\
\hline
\end{tabular}




\begin{tabular}{|c|c|c|}
\hline 610 & $z$ & depth below soil surface \\
\hline 611 & $\alpha$ & footing roughness factor \\
\hline 612 & $\delta_{\text {rem }}$ & remoulded ratio (inverse of sensitivity) \\
\hline 613 & $\sigma_{\mathrm{v} 0}^{\prime}$ & effective vertical stress \\
\hline 614 & $\phi^{\prime}$ & effective friction angle \\
\hline 615 & $\phi_{\mathrm{cv}}$ & constant-volume friction angle of the sand \\
\hline 616 & $\phi_{\text {ini }}$ & initial value of friction angle \\
\hline 617 & $\phi_{\mathrm{p}}$ & peak friction angle \\
\hline 618 & $\psi$ & dilation angle of sand \\
\hline 619 & $\psi_{\mathrm{p}}$ & peak dilation angle \\
\hline 620 & $\gamma^{\prime}$ & effective unit weight of soil \\
\hline 621 & $\gamma_{\mathrm{c}}^{\prime}$ & effective unit weight of clay \\
\hline 622 & $\gamma_{\mathrm{s}}^{\prime}$ & effective unit weight of sand \\
\hline 623 & $\mu$ & rate parameter \\
\hline 624 & $v$ & Poisson's ratio \\
\hline 625 & $\xi$ & absolute cumulative plastic shear strain \\
\hline 626 & $\dot{\xi}$ & maximum shear strain rate \\
\hline 627 & $\Delta \xi$ & incremental plastic shear strain \\
\hline 628 & $\xi_{95}$ & softening parameter \\
\hline 629 & $\xi_{\mathrm{cv}}$ & plastic shear strains corresponding to critical state \\
\hline 630 & $\xi_{\mathrm{p}}$ & plastic shear strains corresponding to peak friction angle \\
\hline 631 & $\dot{\xi}_{\text {ref }}$ & reference shear strain rate at which $s_{\mathrm{u}}$ was assessed \\
\hline 632 & $\Delta \varepsilon$ & incremental principal plastic strain \\
\hline
\end{tabular}




\begin{tabular}{|c|c|c|c|c|c|c|c|c|}
\hline \multirow[t]{2}{*}{ Site } & \multicolumn{2}{|c|}{$\begin{array}{l}\text { Depth below } \\
\text { mudline, z: m }\end{array}$} & \multicolumn{2}{|c|}{$\begin{array}{c}\text { Shear strength, } \\
s_{\mathrm{u}}: \mathbf{k P a}\end{array}$} & \multirow{2}{*}{$\begin{array}{c}\text { Relative } \\
\text { density; } \\
I_{D}(\%)\end{array}$} & \multirow{2}{*}{$\begin{array}{c}\text { Friction, } \\
\text { dilation } \\
\text { angles; } \phi^{\prime} \text {, } \\
\psi\left({ }^{\circ}\right)\end{array}$} & \multirow{2}{*}{$\begin{array}{c}\text { Submerged } \\
\text { unit } \\
\text { weight, } \gamma^{\prime} \text { : } \\
\mathbf{k N} / \mathbf{m}^{3}\end{array}$} & \multirow[t]{2}{*}{ Soil type } \\
\hline & Top & Bottom & $\begin{array}{c}S_{\mathrm{um}} \\
(\mathrm{kPa})\end{array}$ & $\begin{array}{c}k \\
(\mathrm{kPa} / \mathrm{m})\end{array}$ & & & & \\
\hline \multirow[t]{4}{*}{1} & 0.00 & 2.70 & - & - & 22.7 & $33.1,4.4$ & 9.1 & Loose sand \\
\hline & 2.70 & 6.10 & 10.30 & -0.23 & - & - & 4.7 & $\begin{array}{c}\text { Very soft olive grey } \\
\text { clay }\end{array}$ \\
\hline & 6.10 & 10.70 & - & - & 24.4 & $32.3,2.8$ & 7.9 & Loose sand \\
\hline & 10.70 & 27.10 & 14.49 & 1.19 & - & - & 6.3 & $\begin{array}{l}\text { Soft to firm olive } \\
\text { grey clay }\end{array}$ \\
\hline \multirow[t]{2}{*}{2} & 0.00 & 7.00 & - & - & 64.9 & $40.7,20.1$ & 9.4 & $\begin{array}{l}\text { Medium grey fine } \\
\text { sand }\end{array}$ \\
\hline & 7.00 & 56.1 & 17.87 & 1.31 & - & - & 6.7 & $\begin{array}{l}\text { Soft to stiff grey } \\
\text { clay }\end{array}$ \\
\hline \multirow[t]{2}{*}{3} & 0.00 & 4.90 & - & - & 63.7 & 41.1, 21.1 & 9.4 & Medium sand \\
\hline & 4.90 & 52.10 & 22.13 & 0.93 & - & - & 7.3 & $\begin{array}{l}\text { Soft to stiff grey } \\
\text { clay }\end{array}$ \\
\hline \multirow[t]{2}{*}{4} & 0.00 & 4.30 & - & - & 86.2 & $46.3,32.0$ & 8.5 & Very dense sand \\
\hline & 4.30 & 9.60 & 37.42 & 5.71 & - & - & 6.6 & $\begin{array}{l}\text { Firm to stiff dark } \\
\text { greenish grey clay }\end{array}$ \\
\hline \multirow[t]{3}{*}{5} & 0.00 & 3.05 & - & - & 43.1 & $37.6,13.7$ & 8.6 & Medium sand \\
\hline & \multirow[t]{2}{*}{3.05} & \multirow[t]{2}{*}{12.80} & 27.45 & 1.94 & \multirow[t]{2}{*}{-} & \multirow[t]{2}{*}{-} & \multirow[t]{2}{*}{7.5} & \multirow{2}{*}{$\begin{array}{l}\text { Firm olive grey lean } \\
\text { clay }\end{array}$} \\
\hline & & & $18.77^{*}$ & $2.65^{*}$ & & & & \\
\hline
\end{tabular}


Table 2. Summary of jack-up rig and spudcan details

\begin{tabular}{|c|c|c|c|c|c|c|c|c|}
\hline Site & $\begin{array}{l}\text { Jack-up } \\
\text { rig type }\end{array}$ & $\begin{array}{l}\text { Equivalent } \\
\text { diameter, } \\
\text { D: } \mathbf{m}\end{array}$ & $\begin{array}{l}\text { Spudcan } \\
\text { bearing } \\
\text { area, } \\
A: \mathrm{m}^{2}\end{array}$ & $\begin{array}{l}\text { Spudcan } \\
\text { volume, } \\
V: \mathbf{m}^{3}\end{array}$ & $\begin{array}{l}\text { Spudcan } \\
\text { volume } \\
\text { below the } \\
\text { maximum } \\
\text { diameter, } \\
V_{\mathrm{b}} \mathbf{m}^{3}\end{array}$ & $\begin{array}{c}\text { Lightship } \\
+ \text { Variable } \\
\text { load per } \\
\text { spudcan, } \\
Q_{L}: M N\end{array}$ & $\begin{array}{c}\text { Maximum } \\
\text { preload } \\
\text { per } \\
\text { spudcan, } \\
Q_{P}: M N\end{array}$ & $\begin{array}{c}\text { Maximum } \\
\text { bearing } \\
\text { pressure, } \\
\text { q }_{\text {max }}: \mathrm{kPa}\end{array}$ \\
\hline 1 & $\begin{array}{c}\text { MLT 82- } \\
\text { SDC }\end{array}$ & 12.1 & 114.7 & 287.7 & 122.7 & 22.7 & 35.5 & 309.5 \\
\hline 2 & $\begin{array}{l}\text { MLT } \\
116-C\end{array}$ & 13.5 & 143.6 & 382.8 & 75.2 & 35.4 & 53.4 & 371.9 \\
\hline 3 & $\begin{array}{l}\text { MLT 82- } \\
\text { SDC }\end{array}$ & 12.1 & 114.7 & 287.7 & 122.7 & 22.7 & 35.6 & 310.4 \\
\hline 4 & $\begin{array}{l}\text { MLT } \\
116-C\end{array}$ & 13.5 & 143.6 & 382.8 & 75.2 & 33.4 & 56.0 & 390.0 \\
\hline 5 & $\begin{array}{l}\text { MLT 82- } \\
\text { SDC }\end{array}$ & 12.1 & 114.7 & 287.7 & 122.7 & 22.7 & 35.6 & 310.8 \\
\hline
\end{tabular}


Table 3. Summary of relative density equations and the derived values

\begin{tabular}{|c|c|c|c|c|c|c|}
\hline \multirow{2}{*}{ Literature } & \multirow{2}{*}{ Equations } & \multicolumn{5}{|c|}{ Relative density: $I_{D}(\%)$} \\
\hline & & Site 1 & Site 2 & Site 3 & Site 4 & Site 5 \\
\hline \multirow{2}{*}{$\begin{array}{l}\text { Terzaghi } \\
\text { and Peck } \\
(1967)\end{array}$} & \multirow[b]{2}{*}{$I_{\mathrm{D}}(\%)=100 \sqrt{\left(N_{1}\right)_{60} / 60}$} & 22.6 & \multirow[b]{2}{*}{64.7} & \multirow[b]{2}{*}{63.5} & \multirow[b]{2}{*}{85.9} & \multirow[b]{2}{*}{43.0} \\
\hline & & 24.3 & & & & \\
\hline \multirow{2}{*}{$\begin{array}{c}\text { Skempton } \\
\text { (1986) }\end{array}$} & \multirow{2}{*}{\multicolumn{2}{|c|}{$I_{\mathrm{D}}(\%)=100 \sqrt{\frac{0.5 \log \left(\frac{200}{\sigma_{\mathrm{v} 0}^{\prime}}\right) N_{60}}{55}} \quad \frac{25.4}{}$}} & \multirow{2}{*}{67.6} & \multirow{2}{*}{66.3} & \multirow{2}{*}{89.7} & \multirow{2}{*}{44.9} \\
\hline & & & & & & \\
\hline \multirow{2}{*}{$\begin{array}{l}\text { Kulhawy } \\
\text { and Mayne } \\
\text { (1990) }\end{array}$} & \multirow{2}{*}{$I_{\mathrm{D}}(\%)=100 \sqrt{\frac{\left(N_{1}\right)_{60}}{\left[60+25 \log _{10}\left(D_{50}\right)\right] O C R^{0.18}}}$} & 21.8 & \multirow{2}{*}{62.4} & \multirow{2}{*}{61.2} & \multirow{2}{*}{82.8} & \multirow{2}{*}{41.4} \\
\hline & & 23.4 & & & & \\
\hline \multirow{2}{*}{\multicolumn{2}{|c|}{ Average $I_{D}(\%)$}} & 22.7 & \multirow{2}{*}{64.9} & \multirow{2}{*}{63.7} & \multirow{2}{*}{86.2} & \multirow{2}{*}{43.1} \\
\hline & & 24.4 & & & & \\
\hline
\end{tabular}

639

640

641

642

643

644

645

646

647

648

649 
651 Figure 1. Spudcan geometry and dimensions: (a) Marathon LeTourneau Design Class

652

653

654

655

656

657

658

659

660

661

662

663

664

665

666

667

668
82-SDC (MLT 82-SDC); (b) Marathon LeTourneau Design Class 116-C (MLT 116-C)

Figure 2. Site 1: (a) Undrained shear strength profiles of two clay layers; (b) Comparison of measured, predicted and computed load-penetration profiles

Figure 3. Site 2: (a) Undrained shear strength profiles of two clay layers; (b) Comparison of measured, predicted and computed load-penetration profiles

Figure 4. Site 3: (a) Undrained shear strength profiles of two clay layers; (b) Comparison of measured, predicted and computed load-penetration profiles

Figure 5. Site 4: (a) Undrained shear strength profiles of two clay layers; (b) Comparison of measured, predicted and computed load-penetration profiles

Figure 6. Site 5: (a) Undrained shear strength profiles of two clay layers; (b) Comparison of measured, predicted and computed load-penetration profiles 

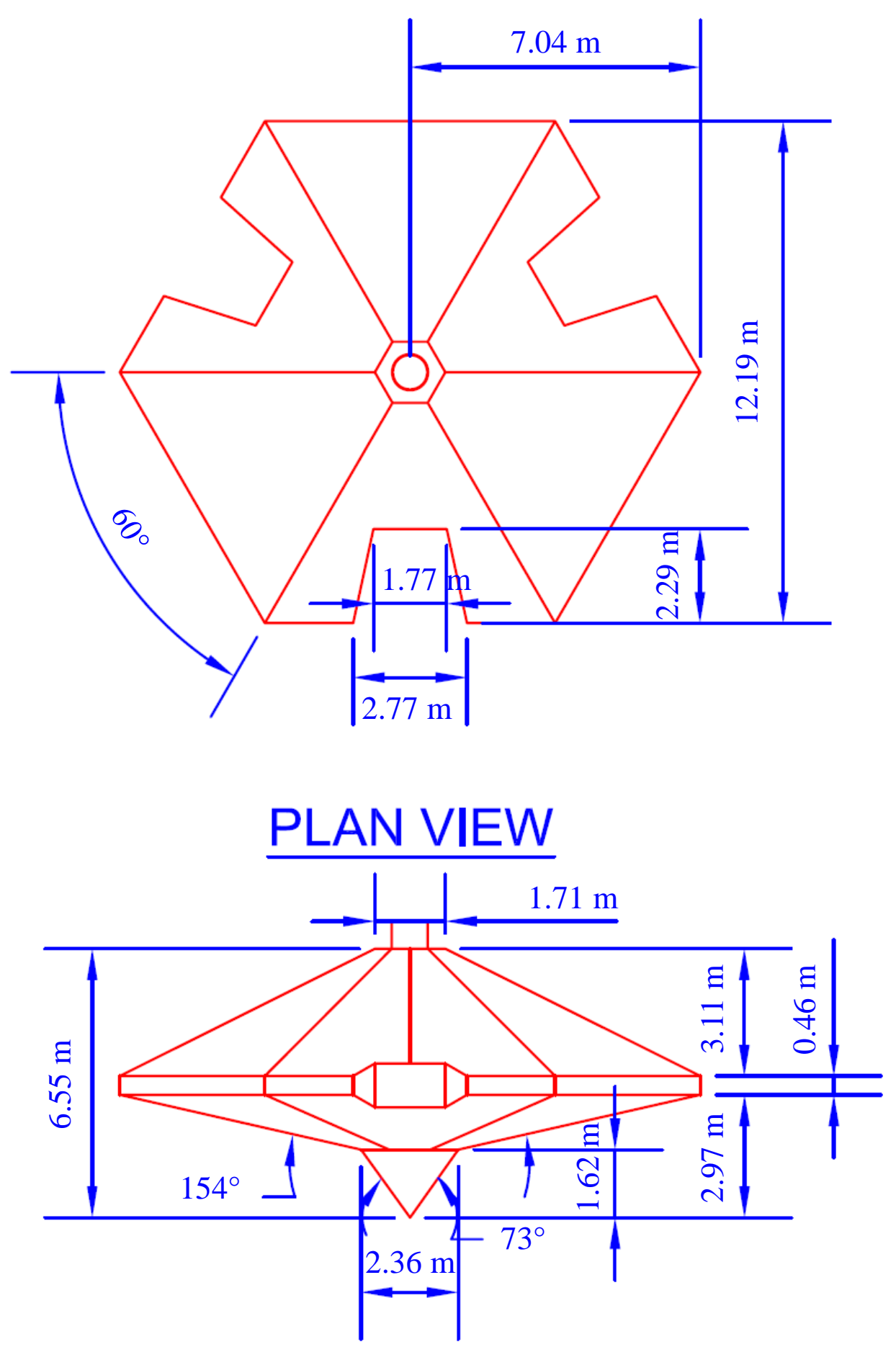

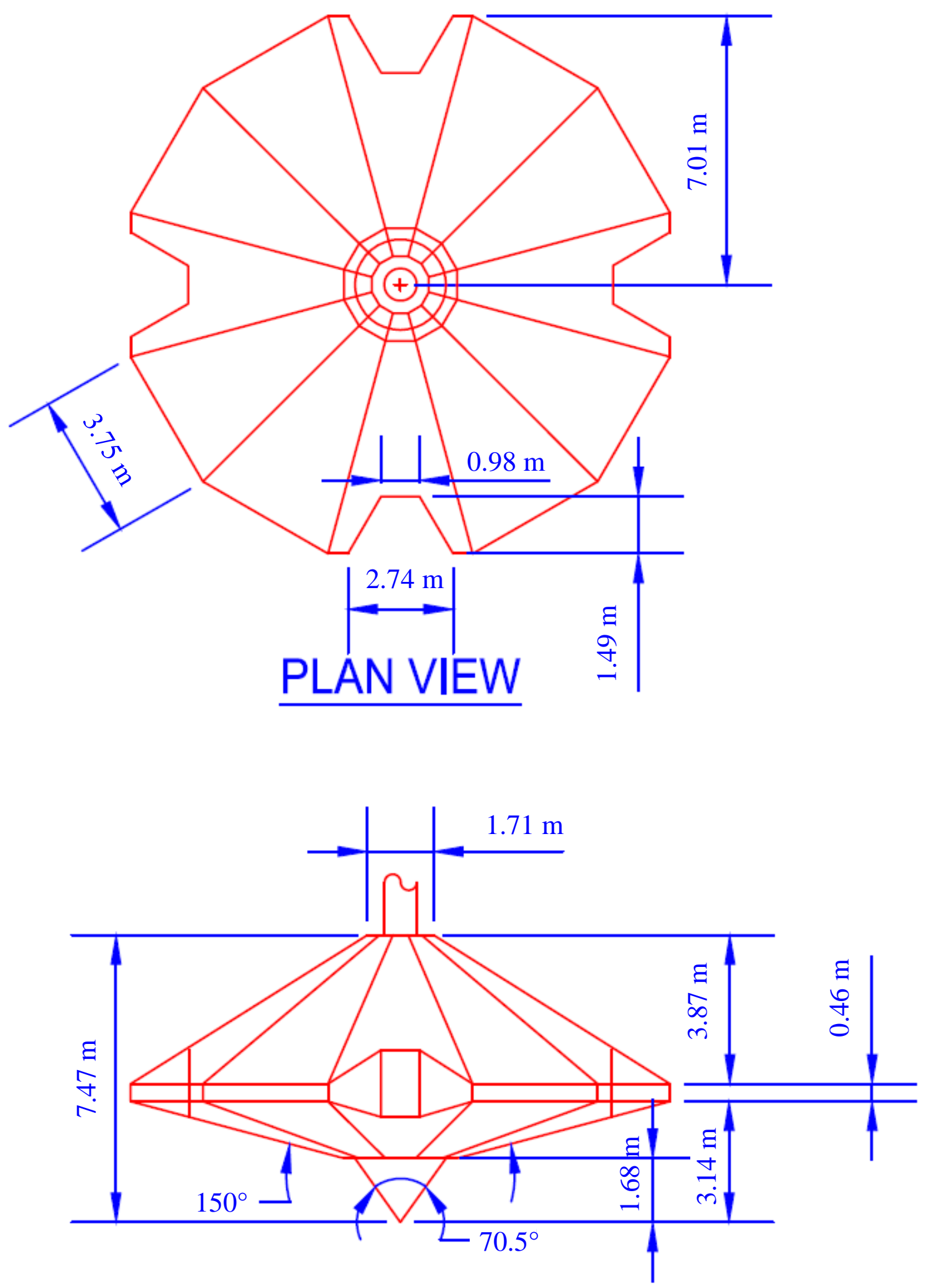

675

(b) Marathon LeTourneau Design Class 116-C (MLT 116-C)

676

677

Fig. 1. Spudcan geometry and dimensions

678

679 


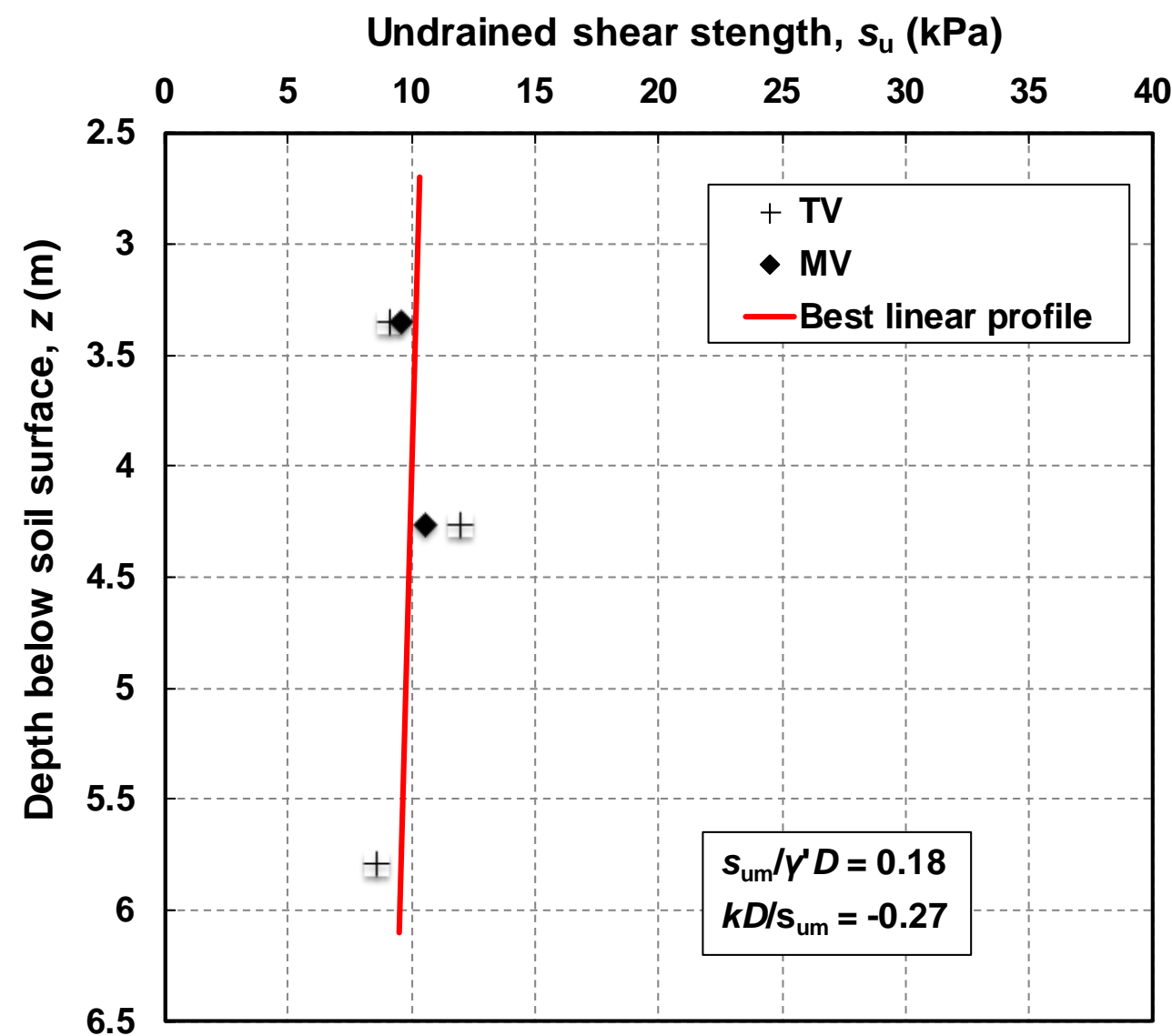

681

682 


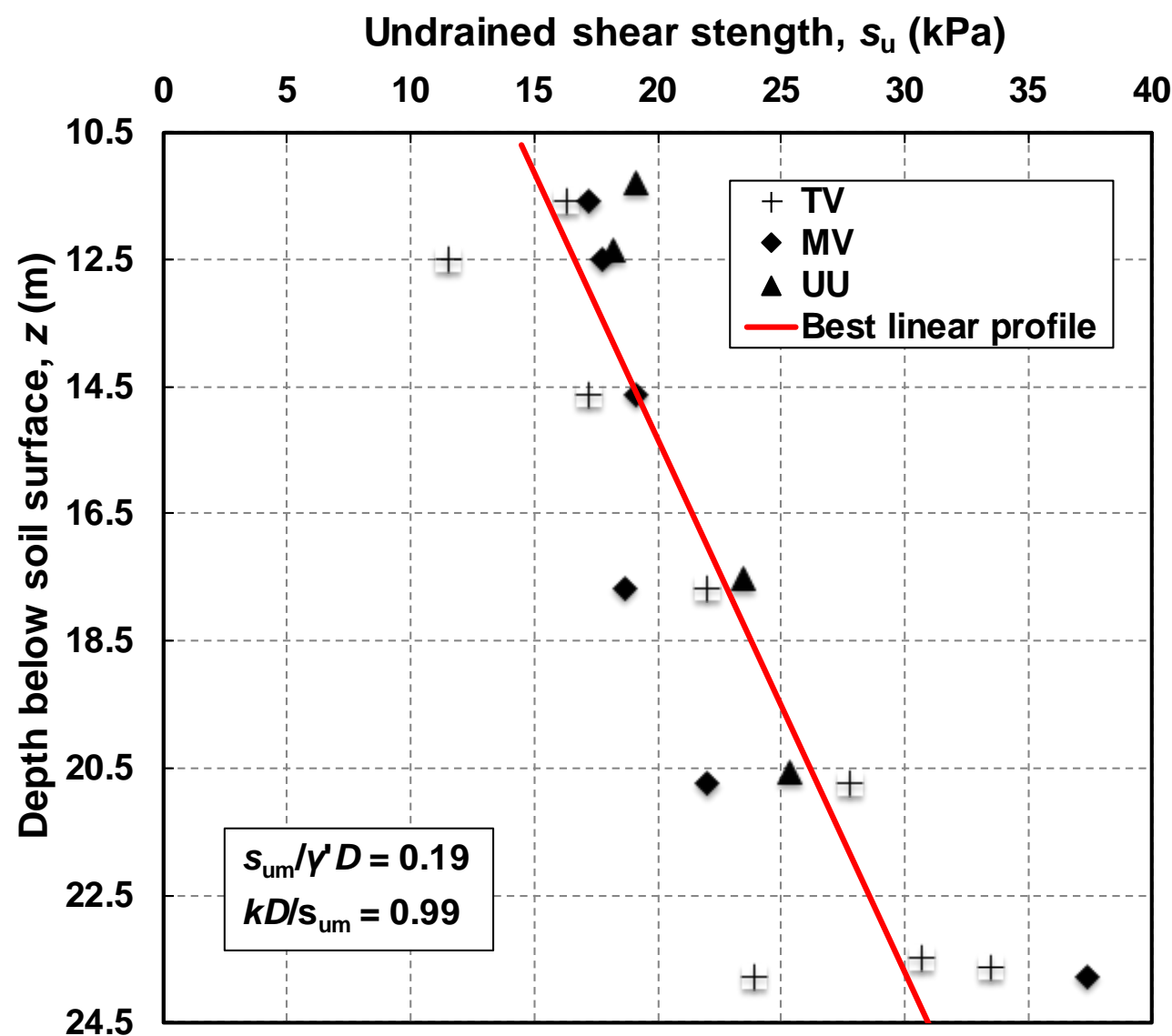

684

a) Undrained shear strength profiles of two clay layers 


\section{Bearing capacity, $Q_{v}(M N)$}

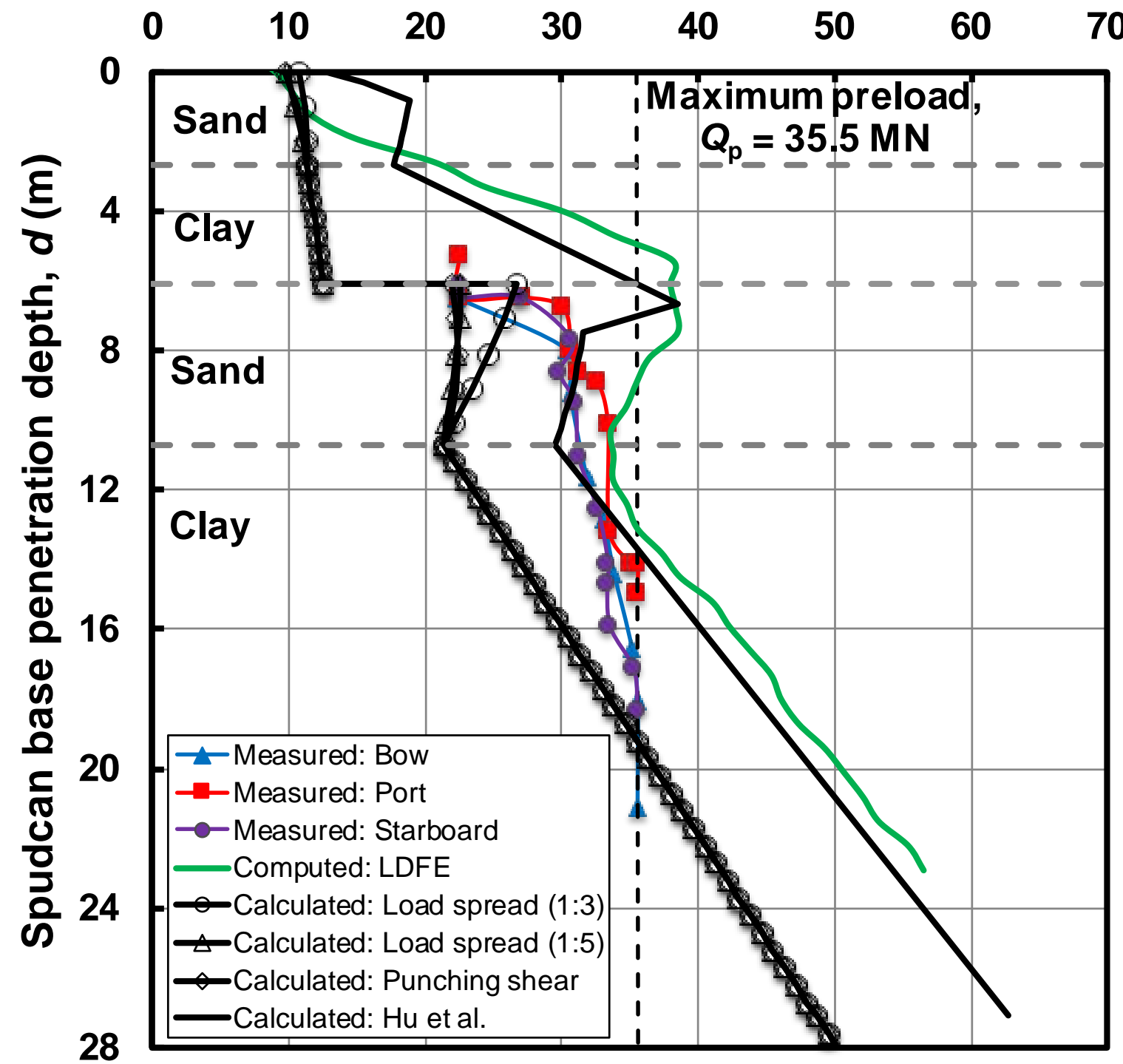

(b) Comparison of measured, predicted and computed load-penetration profiles

Fig. 2. Site 1: (a) Undrained shear strength profiles of two clay layers; (b) Comparison 
699

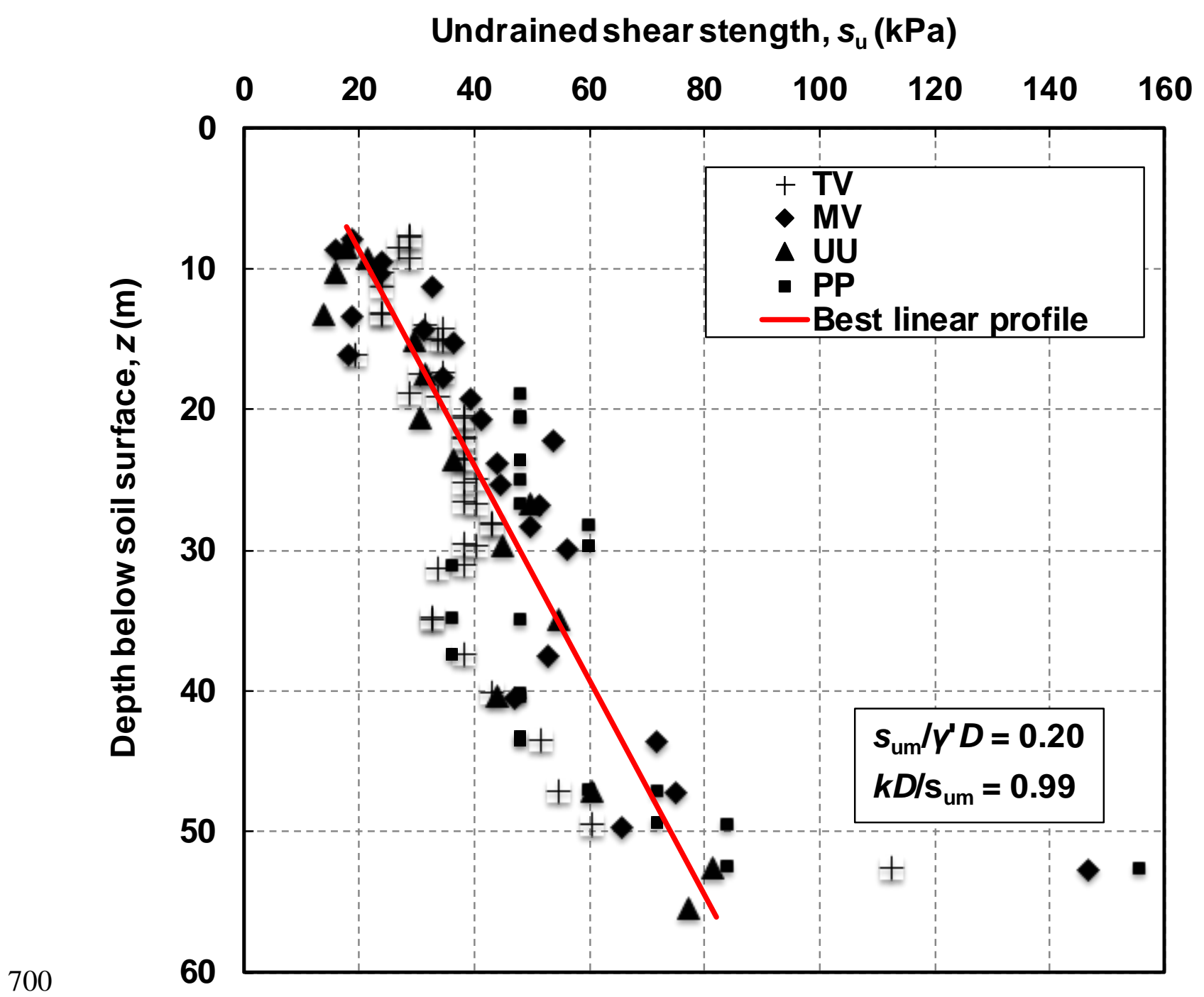

701

(a) Undrained shear strength profile of the clay layer

702

703

704

705

706

707

708

709

710

711

712

713 


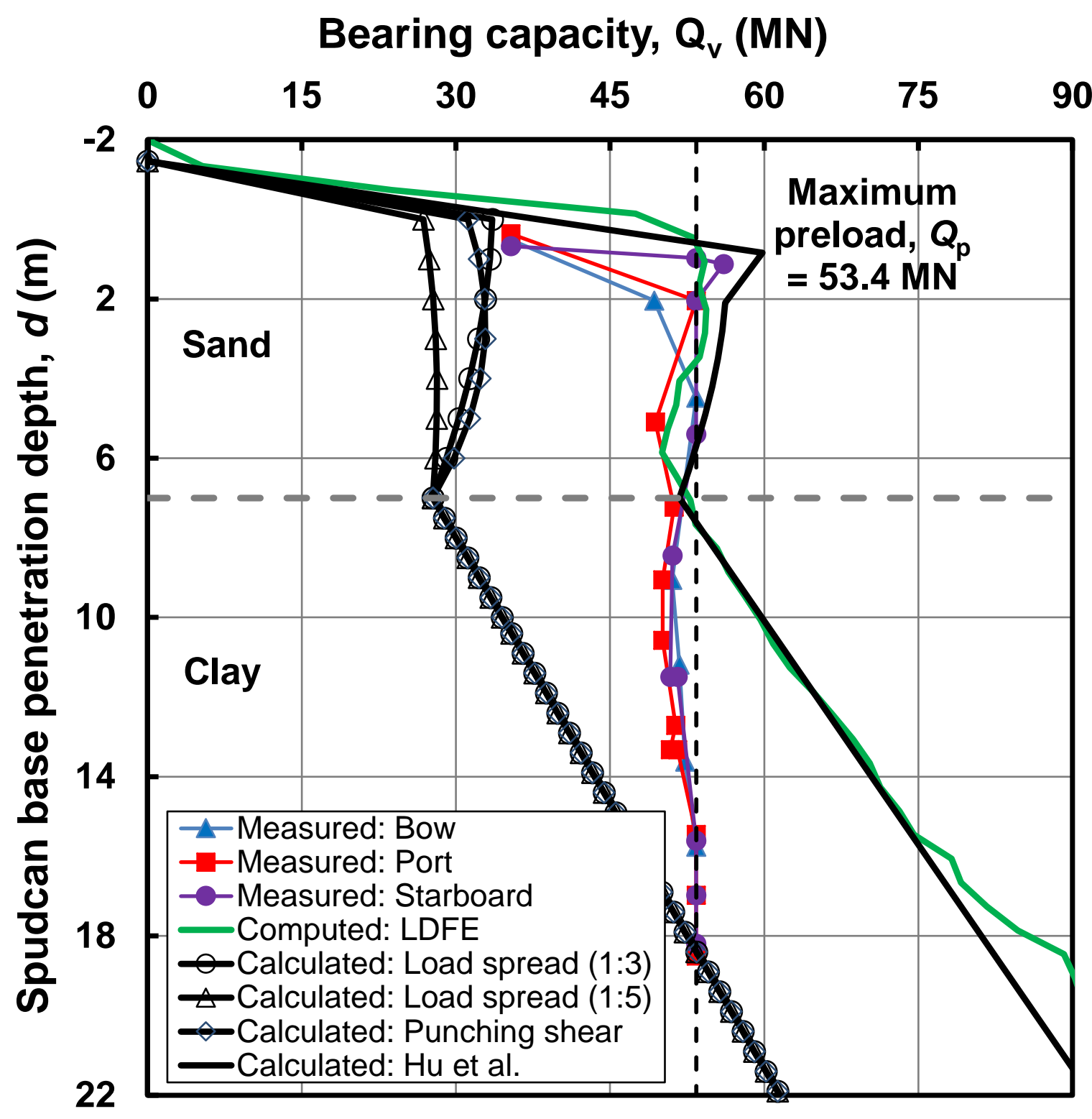

(b) Comparison of measured, predicted and computed load-penetration profiles

Fig. 3. Site 2: (a) Undrained shear strength profile of the clay layer; (b) Comparison of 


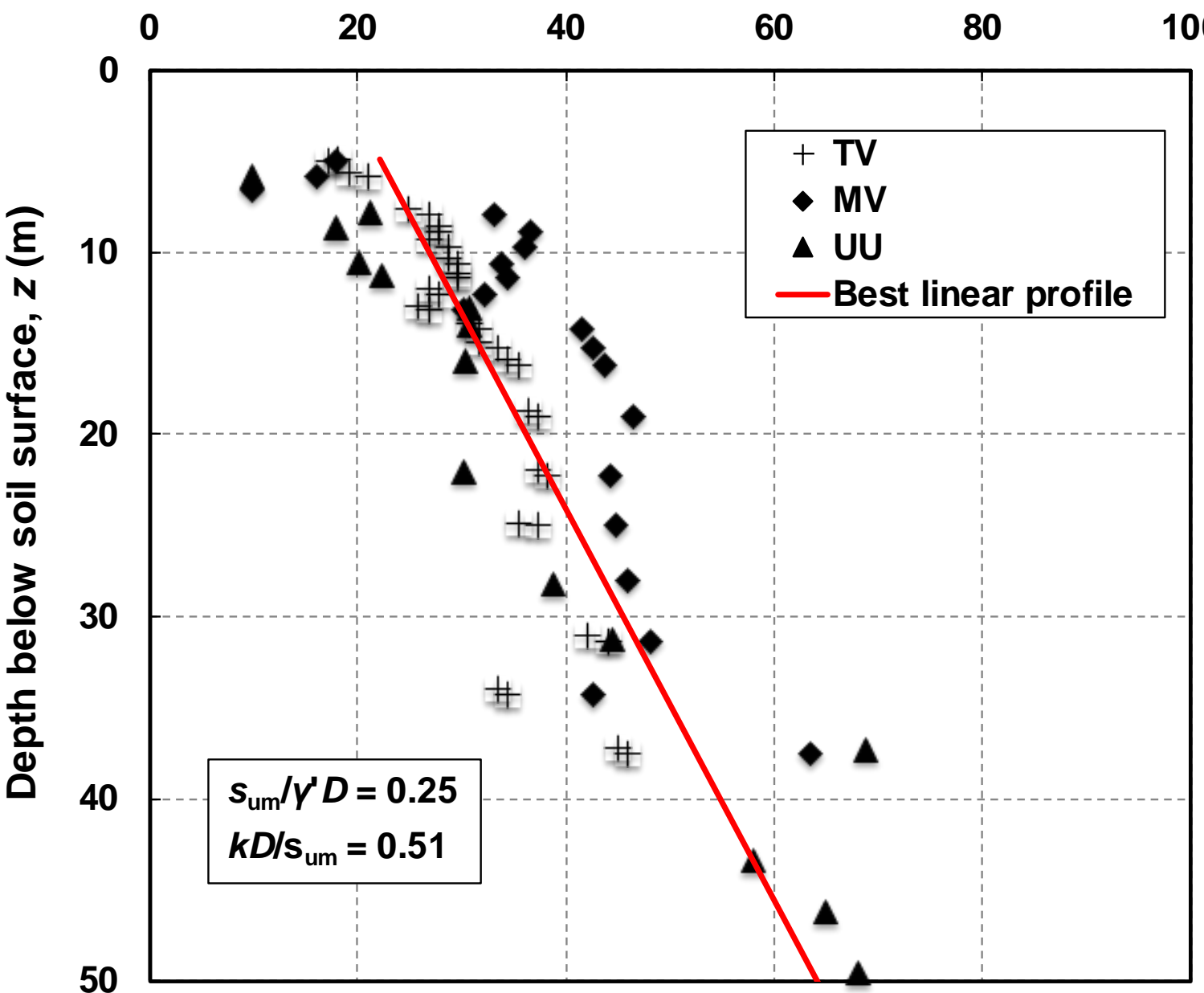

(a) Undrained shear strength profile of the clay layer 


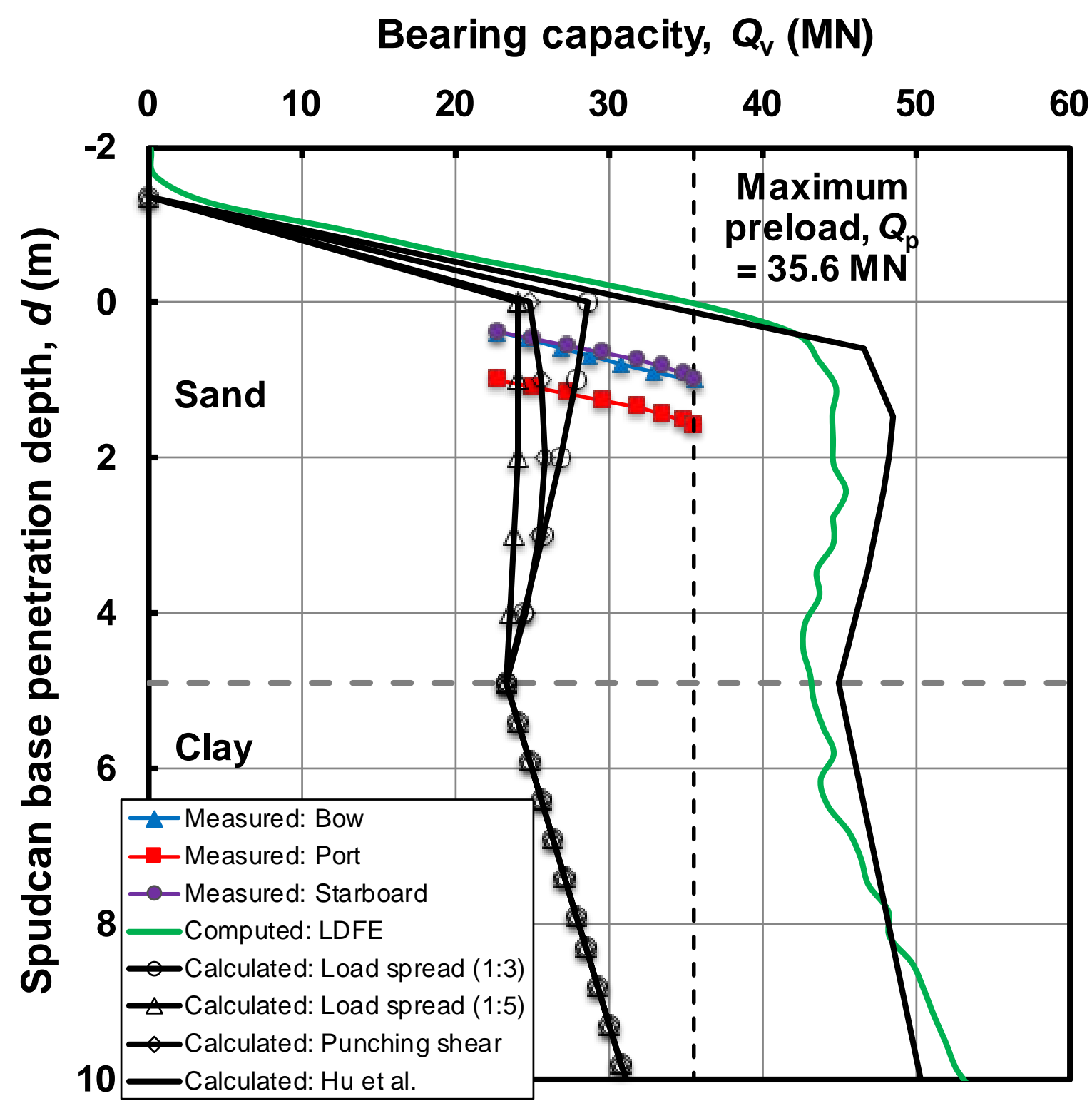

(b) Comparison of measured, predicted and computed load-penetration profiles

Fig. 4. Site 3: (a) Undrained shear strength profile of the clay layer; (b) Comparison of 


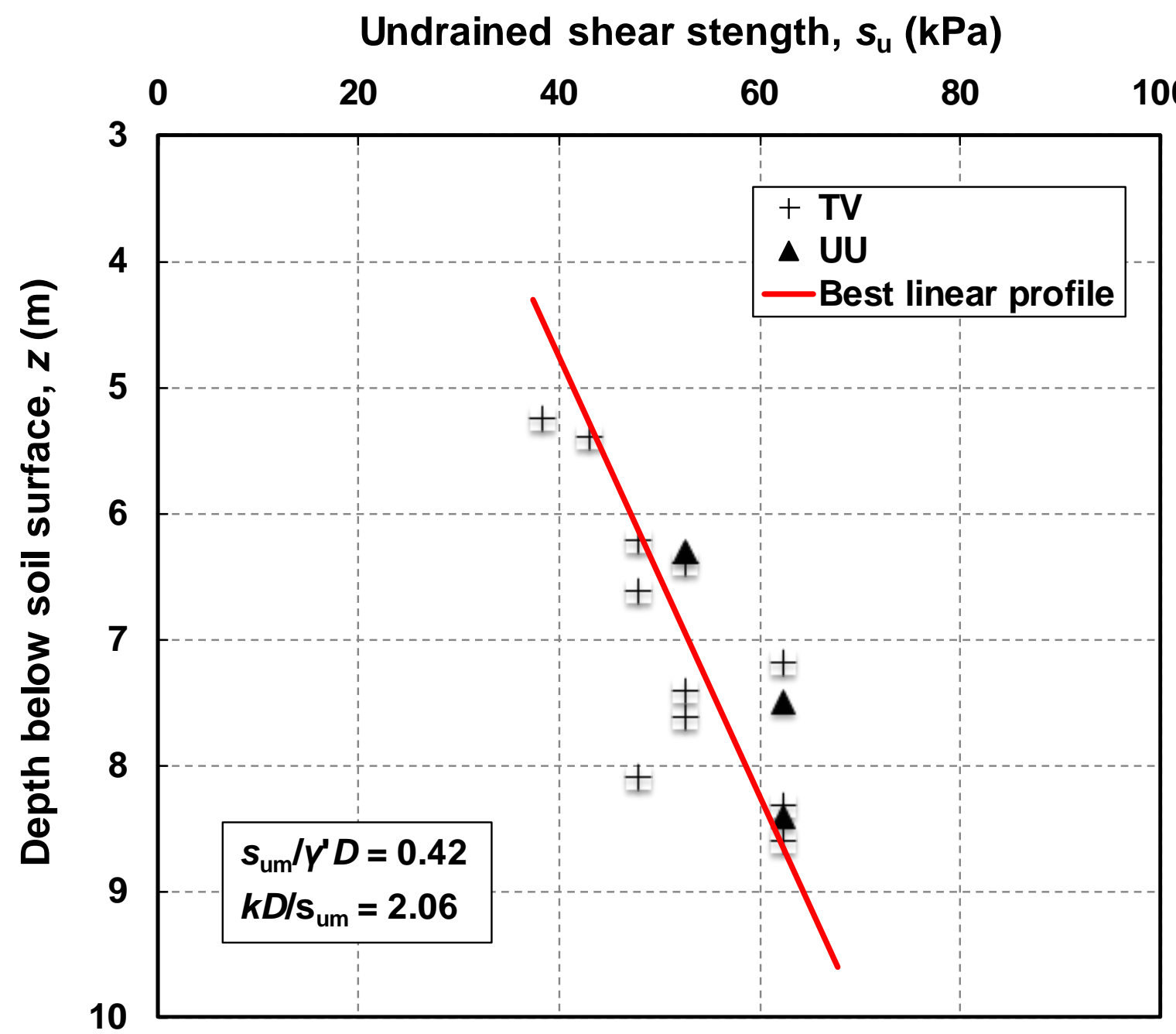

758

(a) Undrained shear strength profile of the clay layer

759

760

761

762

763

764

765

766

767

768

769

770

771 


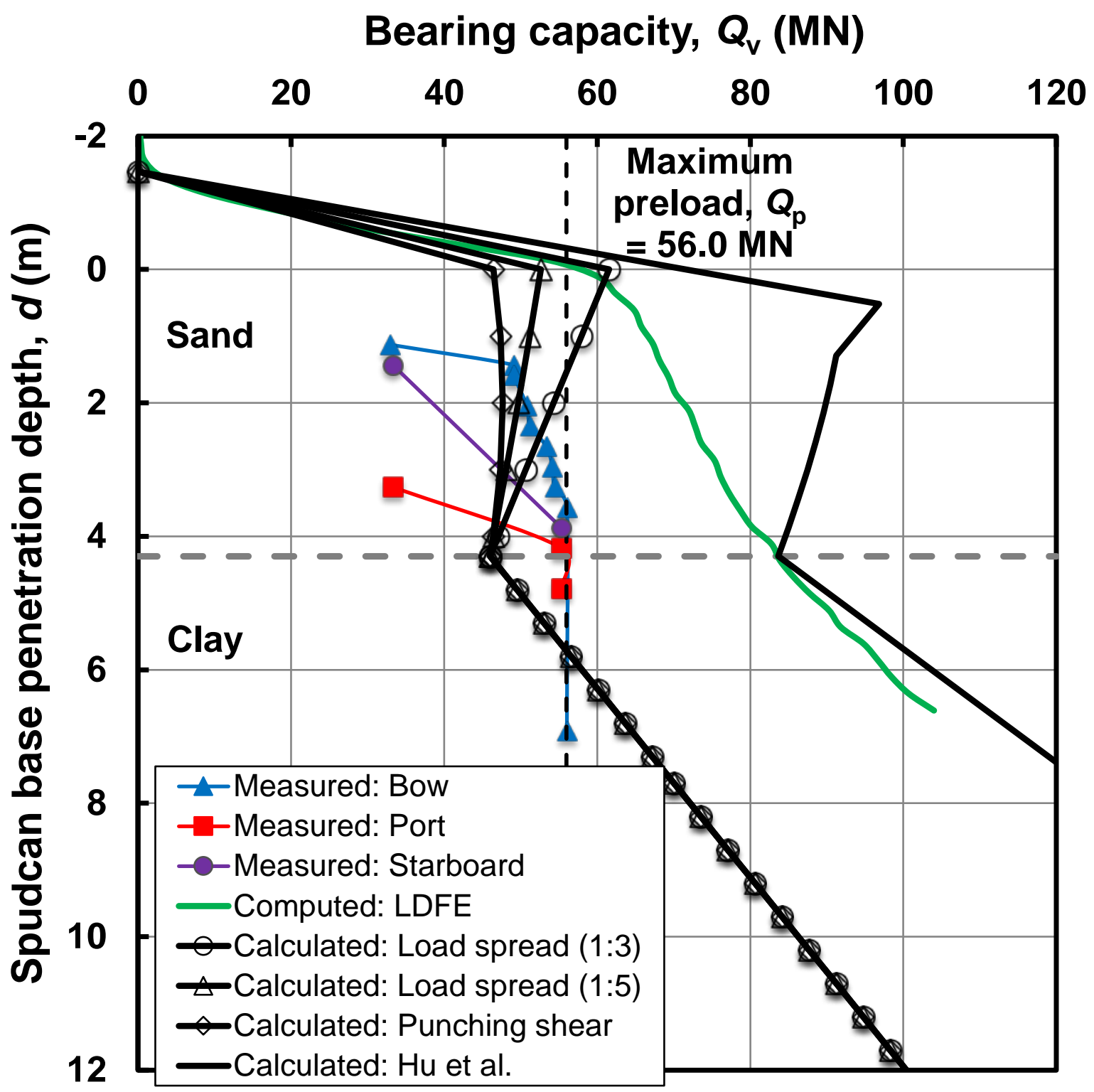

(b) Comparison of measured, predicted and computed load-penetration profiles

Fig. 5. Site 4: (a) Undrained shear strength profile of the clay layer; (b) Comparison of 


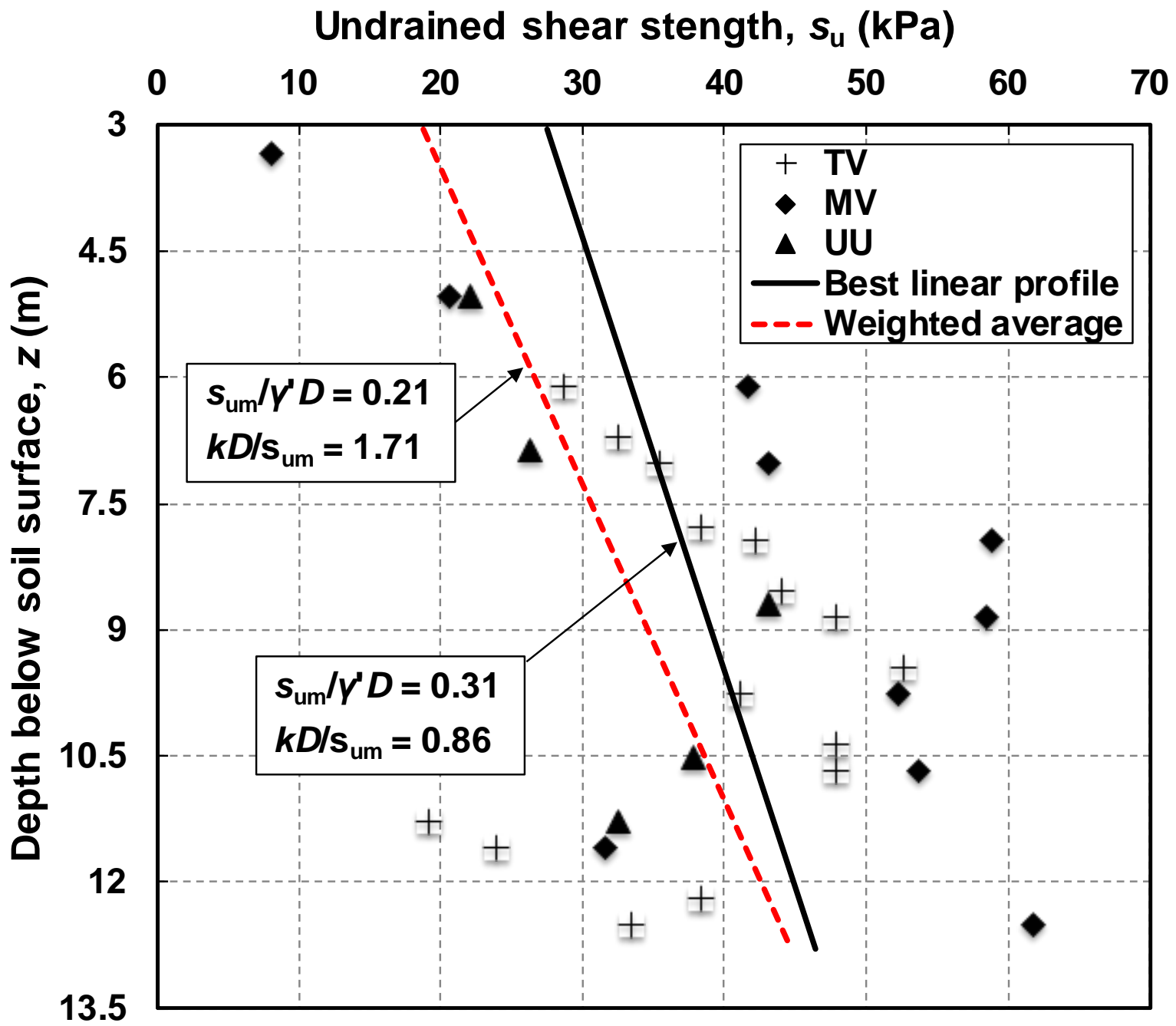

(a) Undrained shear strength profile of the clay layer 


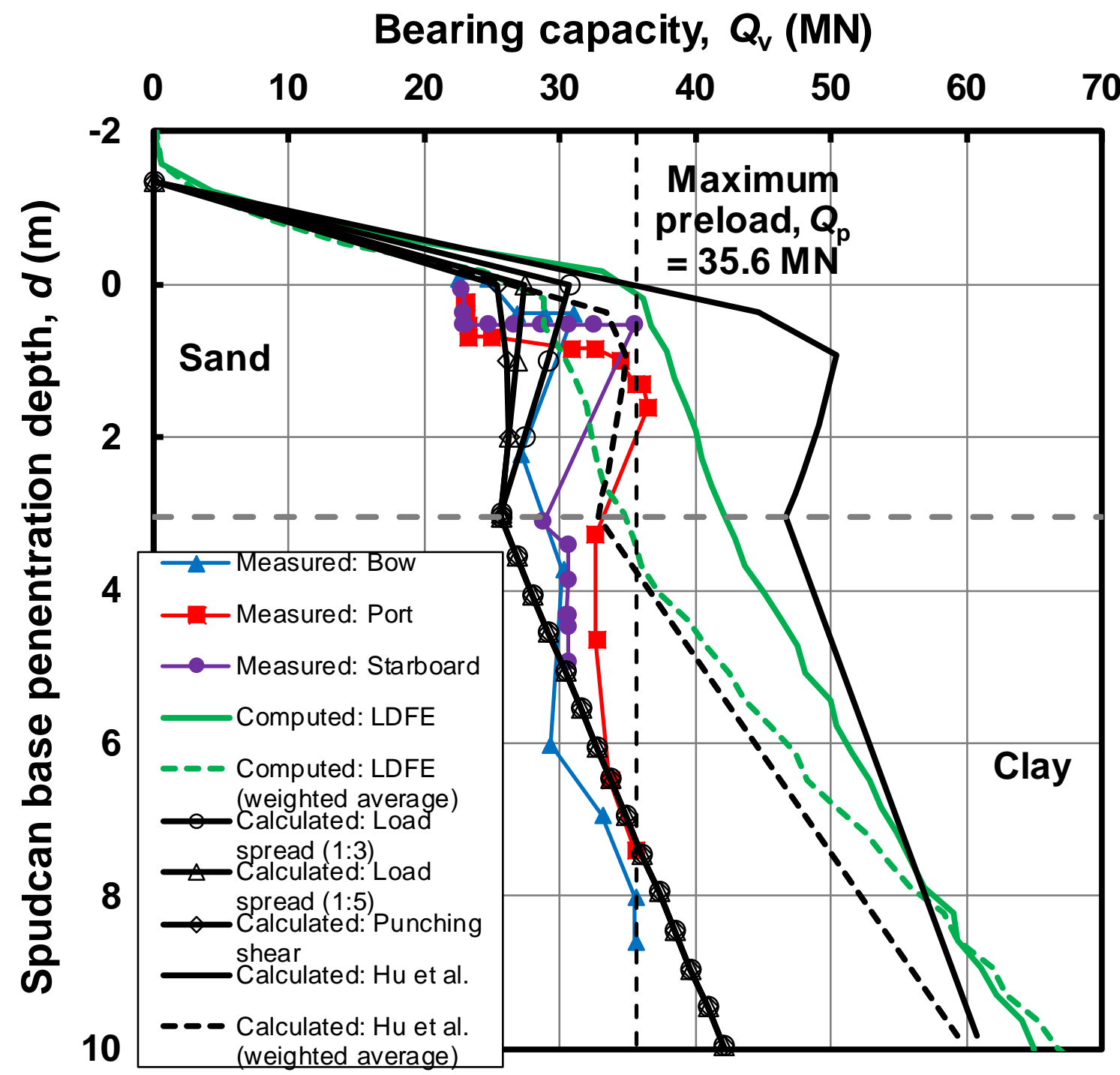

803

(b) Comparison of measured, predicted and computed load-penetration profiles

804

805

Fig. 6. Site 5: (a) Undrained shear strength profile of the clay layer; (b) Comparison of 806 measured, predicted and computed load-penetration profiles 


\section{APPENDIX}

Table 1. Full profile design equations for the ISO methods and Hu et al. approach

\begin{tabular}{|c|c|c|c|c|}
\hline Method & Equations & & & bles \\
\hline $\begin{array}{l}\text { ISO } \\
\text { methods }\end{array}$ & $\begin{array}{l}\text { Load spread method: } \\
Q_{\mathrm{v}}=Q_{\mathrm{u}, \mathrm{b}}-0.25 \pi\left(D+2 \frac{t}{n_{\mathrm{s}}}\right)^{2} t \gamma_{\mathrm{s}}^{\prime} \\
Q_{\mathrm{u}, \mathrm{b}}=s_{\mathrm{u}} N_{\mathrm{c}} 0.25 \pi\left(D+2 \frac{t}{n_{\mathrm{s}}}\right)^{2}+\gamma_{\mathrm{s}}^{\prime}\left[0.25 \pi\left(D+2 \frac{t}{n_{\mathrm{s}}}\right)^{2} H_{\mathrm{s}}+V_{\mathrm{b}}\right] \\
\text { Punching shear method: } \\
Q_{\mathrm{v}}=Q_{\mathrm{u}, \mathrm{b}}-0.25 \pi D^{2} t \gamma_{\mathrm{s}}^{\prime}+0.5 \pi D^{2} t\left[t \gamma_{\mathrm{s}}^{\prime}+2 \gamma_{\mathrm{s}}^{\prime}\left(H_{\mathrm{s}}-t\right)\right] \frac{K_{\mathrm{s}} \tan \phi^{\prime}}{D} \\
Q_{\mathrm{u}, \mathrm{b}}=s_{\mathrm{u}} N_{\mathrm{c}}\left(0.25 \pi D^{2}\right)+\gamma_{\mathrm{s}}^{\prime}\left(0.25 \pi D^{2} H_{\mathrm{s}}+V_{\mathrm{b}}\right)\end{array}$ & (1) & $\begin{array}{l}d \\
D \\
D_{\mathrm{F}} \\
E^{*} \\
E^{*} \\
H_{\text {plug }} \\
H_{\mathrm{s}} \\
k \\
K_{\mathrm{s}} \\
n_{\mathrm{s}} \\
N_{\mathrm{c}} \\
N_{\mathrm{c} 0}\end{array}$ & $\begin{array}{l}\text { penetration depth of spudcan base } \\
\text { diameter of the spudcan } \\
\text { distribution factor } \\
\text { parameter to simplify the algebra } \\
\text { parameter to simplify the algebra } \\
\text { sand plug height } \\
\text { sand thickness } \\
\text { strength gradient of clay } \\
\text { punching shear coefficient } \\
\text { load spread factor } \\
\text { bearing capacity factor } \\
\text { bearing capacity factor of clay at base level of a } \\
\text { circular foundation }\end{array}$ \\
\hline $\begin{array}{l}\text { Hu et a } \\
\text { approac }\end{array}$ & $\begin{aligned} & q_{\text {peak }}=\left(N_{\mathrm{c} 0} s_{\mathrm{um}}+q_{0}+0.12 \gamma_{\mathrm{s}}^{\prime} H_{\mathrm{s}}\right)\left(1+\frac{1.76 H_{\mathrm{s}}}{D} \tan \psi\right)^{E^{*}} \\
&+\frac{\gamma_{\mathrm{s}}^{\prime} D}{2 \tan \psi\left(E^{*}+1\right)}\left[1-\left(1-\frac{1.76 H_{\mathrm{s}}}{D} E^{*} \tan \psi\right)\left(1+\frac{1.76 H_{\mathrm{s}}}{D} \tan \psi\right)\right. \\
& N_{\mathrm{c} 0}= 6.34+0.56 \frac{k\left(D+1.76 H_{\mathrm{s}} \tan \psi\right)}{s_{\mathrm{um}}} \\
& \text { (6) } E^{*}=2\left[1+D_{\mathrm{F}}\left(\frac{\tan \phi^{*}}{\tan \psi}-1\right)\right] \\
&(7) \\
& D_{\mathrm{F}}=0.642\left(\frac{H_{\mathrm{s}}}{D}\right)^{-0.576} \text { as } 0.16 \leq \frac{H_{\mathrm{s}}}{D} \leq 1.0\end{aligned}$ & (8) & $\begin{array}{l}q_{0} \\
q_{\mathrm{clay}} \\
Q_{\mathrm{u}, \mathrm{b}} \\
Q_{\mathrm{v}} \\
S_{\mathrm{u}} \\
S_{\mathrm{u} 0} \\
S_{\mathrm{um}} \\
t \\
V_{\mathrm{b}} \\
\gamma_{\mathrm{c}}^{\prime} \\
\gamma_{\mathrm{s}}^{\prime} \\
\phi^{\prime} \\
\phi^{*}\end{array}$ & $\begin{array}{l}\text { effective overburden pressure } \\
\text { penetration resistance in the clay layer } \\
\text { ultimate vertical bearing capacity of the fictitious } \\
\text { footing } \\
\text { vertical bearing capacity of a spudcan } \\
\text { undrained shear strength of clay } \\
\text { clay shear strength at lowest level of the spudcan } \\
\text { widest cross-sectional area } \\
\text { shear strength of clay at sand-clay interface } \\
\text { thickness of the sand layer in the ISO methods } \\
\text { volume of spudcan below maximum bearing area } \\
\text { effective unit weight of clay } \\
\text { effective unit weight of sand } \\
\text { friction angle of sand } \\
\text { reduced friction angle due to non-associated flow } \\
\text { rule }\end{array}$ \\
\hline
\end{tabular}




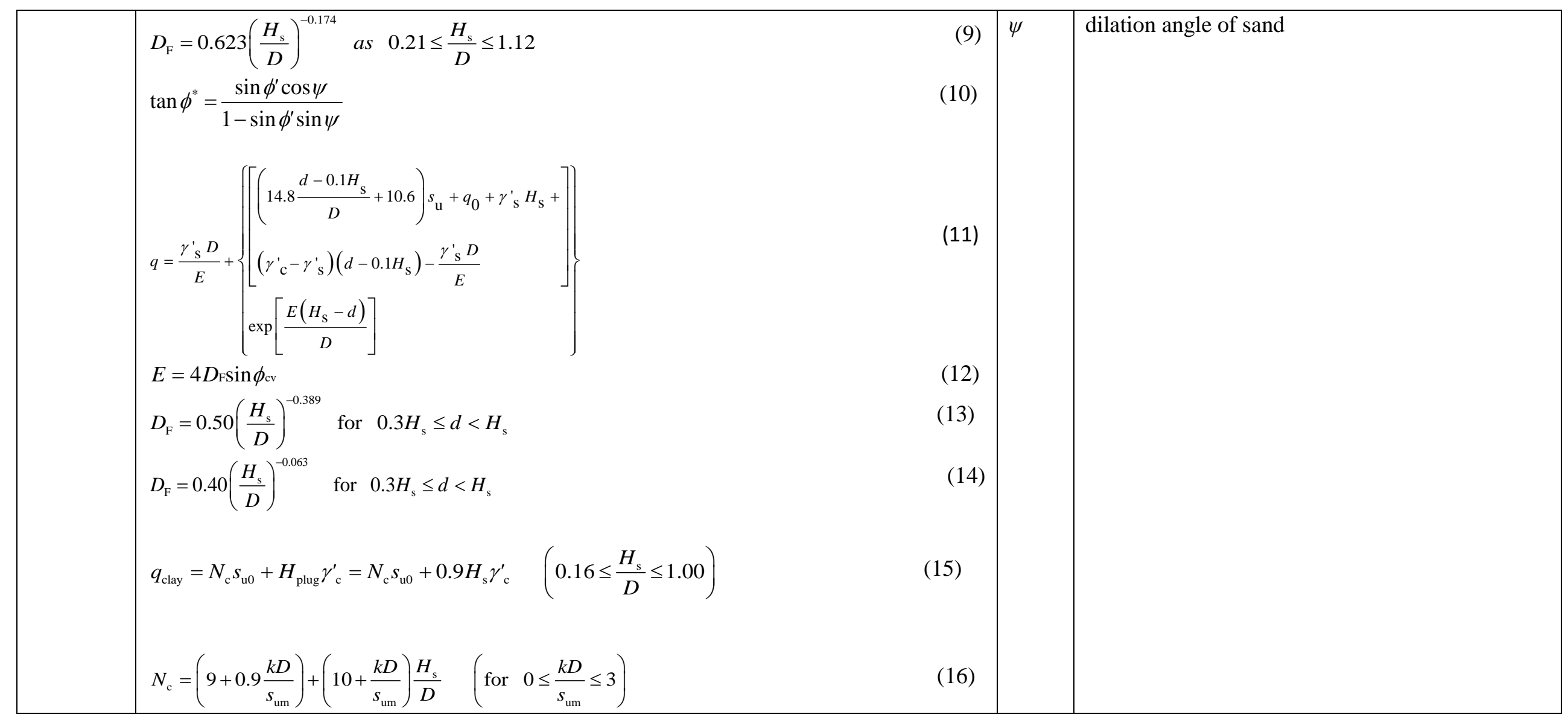


